\title{
Seresta para Piano e Orquestra de Câmara - Culminância da Produção de Camargo Guarnieri no Gênero
}

\author{
Cynthia Priolli
}

\section{Introdução}

Camargo Guarnieri sempre manteve com o piano uma relação íntima e afetiva, considerando-o, durante toda a vida, seu instrumento favorito. Desde a mais tenra infância, ao lado do aprendizado do instrumento com o professor Virgínio Dias, na pequena cidade de Tietê, no interior de São Paulo, onde nasceu, ele já improvisava valsas e outros gêneros populares comuns às zonas paulistas, rural e urbana.

O talento inato para a composição gerou uma jactanciosa reação por parte de seu professor, que, ao tomar contato com a primeira incursão do jovem na arte de compor, através da valsa Sonho de Artista, escrita aos 13 anos de idade e dedicada ao mestre, declarou a seu pai que ele nunca seria um compositor. O tempo encarregou-se de desmascarar a falsa profecia, pois Guarnieri atravessou mais de 60 anos de proficua atividade, recebendo aclamação de "Maior Compositor Contemporâneo das Três Américas", auferida pela Organização dos Estados Americanos (OEA) com a concessão do prêmio "Gabriela Mistral", em 1992, poucos meses antes de falecer. 
A identificação com o instrumento determinou a criação de inúmeras obras para piano solo, dentre as quais os 50 Ponteios estabeleceram-se como uma das mais importantes realizações da literatura pianística nacional. Desde cedo, no entanto, Guarnieri aspirou por obras maiores, encontrando no gênero piano-orquestra um eficiente meio para a expressão de sua marcante linguagem pessoal.

Lançado oficialmente como compositor em 1928, pelas mãos do mentor Mário de Andrade, já aos 24 anos, em 1931, vemos surgir seu primeiro concerto para piano e orquestra, que inaugura uma série de seis obras do mesmo gênero, assim dispostas cronologicamente: segundo concerto, 1946; terceiro, 1964; quarto, 1968; quinto, 1970; sexto, 1987.

Tive o privilégio de assistir à criação do último $\operatorname{deles}^{1}$ que, originalmente, foi concebido como Sarati (Três movimentos para piano, orquestra de cordas e percussão), constituindo uma encomenda do Itamaraty para comemorar o octogésimo aniversário do compositor. O curioso título foi sugestão do musicólogo e, então, embaixador do Brasil Vasco Mariz que, em um encontro no estúdio de Guarnieri, ao qual também estivemos presentes, sugeriu ao compositor: "Você deveria escrever uma obra com o nome Sarati, em homenagem ao nome do edificio onde se localiza o seu estúdio". $\mathrm{E}$ assim nasceram os três movimentos para piano, orquestra de cordas e percussão, que Guarnieri, após a ampliação da cadência do piano solista no primeiro movimento, decidiu denominar Concerto $n{ }^{\circ} \sigma$ para piano e orquestra, mantendo o subtítulo proposto pelo amigo - Sarati.

Além da produção em série, Guarnieri persiste no gênero em obras individuais. De sua lavra nasceram:

Variações sobre um tema nordestino - 1953;

Choro para piano e orquestra - 1956;

Concertino para piano e orquestra de câmara - 1961;

Seresta para piano e orquestra de camara - 1965;

Do total de dez obras destinadas ao gênero piano-orquestra, quatro receberam importantes prêmios nacionais e internacionais, a saber: 
* Concerto $n^{\circ} 2$ para piano e orquestra - $1^{\circ}$ prêmio no Concurso Alexandre Levy, em São Paulo - 1946;

* Choro para piano e orquestra - 1ำ prêmio no Festival Latino-Americano de Caracas, Venezuela - 1956;

* Concertino para piano e orquestra de câmara - Medalha de Prata como melhor obra sinfônica pela Associação Paulista de Críticos Teatrais - 1963;

* Seresta para piano e orquestra de câmara - Medalha de Prata como melhor obra de câmara pela Associação Paulista de Críticos Teatrais - 1965; Prêmio Golfinho de Ouro do Museu da Imagem e do Som - 1968.

O estreito convívio de aproximadamente 12 anos com Camargo Guarnieri concedeu-me a especialíssima oportunidade de trabalhar inúmeras de suas obras sob sua própria supervisão, fato que me permitiu experienciar, de maneira abundante e rica, a extrema clareza de seu pensamento criador, ao lado de uma aguda sensibilidade, que sempre colocou a emoção como destinação final da obra, como constatamos através de suas próprias palavras: "Para mim, música é emoção, e o principal é saber-me sentido e não simplesmente ouvido"2.

A primeira obra para piano e orquestra de Guarnieri que me chamou a atenção, como intérprete, causando um forte impacto após sua audição, foi a Seresta para piano e orquestra de câmara. Imediatamente, instalou-se em mim o desejo de trabalhá-la junto ao autor, que acolheu a idéia com grande receptividade. $O$ entusiasmo pela obra levou-me a excutá-la inúmeras vezes, a primeira das quais sob a regência do próprio compositor, com a Orquestra Sinfônica do Teatro Nacional de Brasília, em 1984. Recentemente, tive a oportunidade de registrá-la pela primeira vez em CD, com a Orquestra Sinfồnica da Universidade de São Paulo, sob a regência de Ronaldo Bologna, num trabalho inteiramente dedicado à produção guarnieriana.

Composta em 1965, num curto espaço de tempo, que pode ser constatado na redução para piano e orquestra através das datas inseridas ao final dos $1^{\circ}$ e 3 o movimentos - 13/05/65 (término do primeiro movimento) e 10/07/65 (conclusão do terceiro) -, a obra 
foi uma encomenda da Sociedade de Cultura Artística de São Paulo, com a finalidade de encerrar a temporada de concertos da Orquestra de Câmara Pró-Música. Sua estréia ocorreu em 5 de novembro do mesmo ano, no Teatro Municipal de São Paulo, tendo Roberto Schnorrenberg à frente da referida orquestra e a pianista Anna Stella Schic, a quem a obra é dedicada, como solista.

Trata-se de uma obra definitiva e renovadora no universo criador de Camargo Guarnieri, em que o compositor utiliza uma linguagem na qual, segundo sua própria análise, "somente a quintessência dos elementos nativos aparece"3. São pequenas células melódicas alusivas aos arabescos flautísticos dos choros no primeiro movimento, a diluição da nossa popular modinha no 1 o tema do movimento central, ou ainda o tema característico da embolada ao início do $3^{\circ}$ movimento.

A extraordinária coerência desses elementos, norteadora do pensamento guarnieriano numa única direção durante toda a sua vida produtiva, é aqui manifesta através de uma linguagem avançada, com total liberdade harmônica e extrema abrangência e complexidade dos módulos rítmicos, destinando a obra à culminância da produção do autor no gênero.

O nome Seresta, sinônimo de serenata, pode-se tornar dúbio ao examinarmos o significado intrínseco do termo, ou seja, "música de conjunto instrumental, geralmente cantada, melodiosa e simples, algo semelhante às trovas dos cantadores ambulantes, excutada ao ar livre, não raro sob a janela de alguém"4 . Sob esse prisma, sem qualquer dúvida, o termo seria insólito, pois a obra é poderosamente instigante, ousada e complexa. No entanto, através da completa diluição dos elementos de caráter nacional, pode-se observar a ocorrência de certas linhas melódicas características dos conjuntos de choro, a presença de inflexões modinheiras do nosso cancioneiro, tudo isso de forma muito depurada, absorvida pelo inconsciente do compositor e transfigurada no instante da criação.

Camargo Guarnieri, confirmando a própria conduta, valeu-se do idioma pátrio para a indicação dos movimentos, dividindo a obra em três partes: Decidido, Sorumbático e Gingando. 


\section{Análise da Obra}

\subsection{Decidido}

O primeiro movimento, Decidido, é monotemático e está construído na forma sonata, ou seja, exposição, desenvolvimento, reexposição e coda ${ }^{5}$.

À orquestra é dado um tratamento de Concerto Grosso, com alternância entre solo e tutti.

Após uma introdução de quatro compassos, em que blocos sucessivos de sétimas (acordes quebrados em superposição de intervalos de quarta) são apresentados em seqüência ascendente no piano, o instrumento solista, apoiado pelas violas e violoncelos, expõe o tema principal.

Exemplo 1 - comp. 1-7

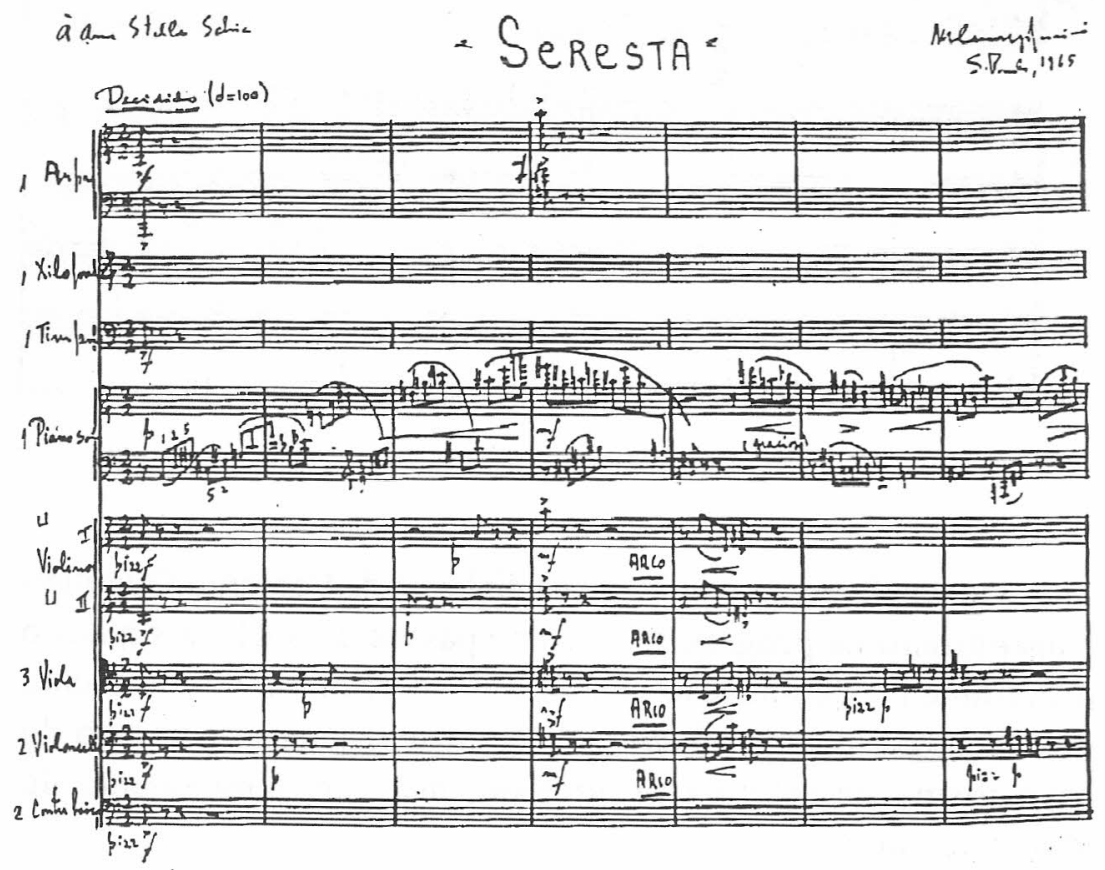


O procedimento canônico, recurso amplamente utilizado pelo compositor e que, ao lado das seqüências por blocos de sétimas, constituirá elemento preponderante na construção do $l^{\circ}$ movimento, pode ser observado logo à entrada do tema no instrumento solista, afirmando-se a seguir entre o piano e os solos de violino e viola.

Exemplo 2 - comp. 8-13

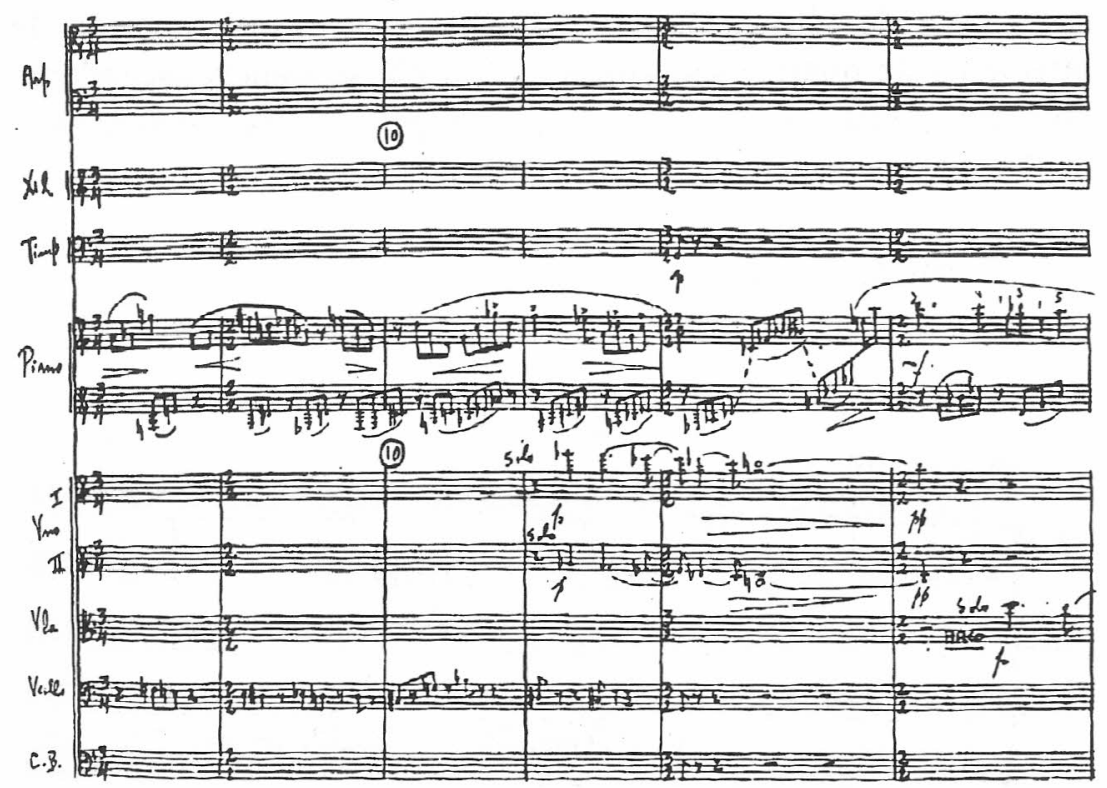

Outro elemento constante na dialética de Camargo Guarnieri é encontrado na progressão dos compassos 27 a 41, nos quais o procedimento de imitação canônica proporciona o deslocamento dos acentos rítmicos (décalage). Nota-se o intenso emprego do cromatismo na referida progressão, mais um componente do idiomático do autor. 
Exemplo 3 - comp. 27-31

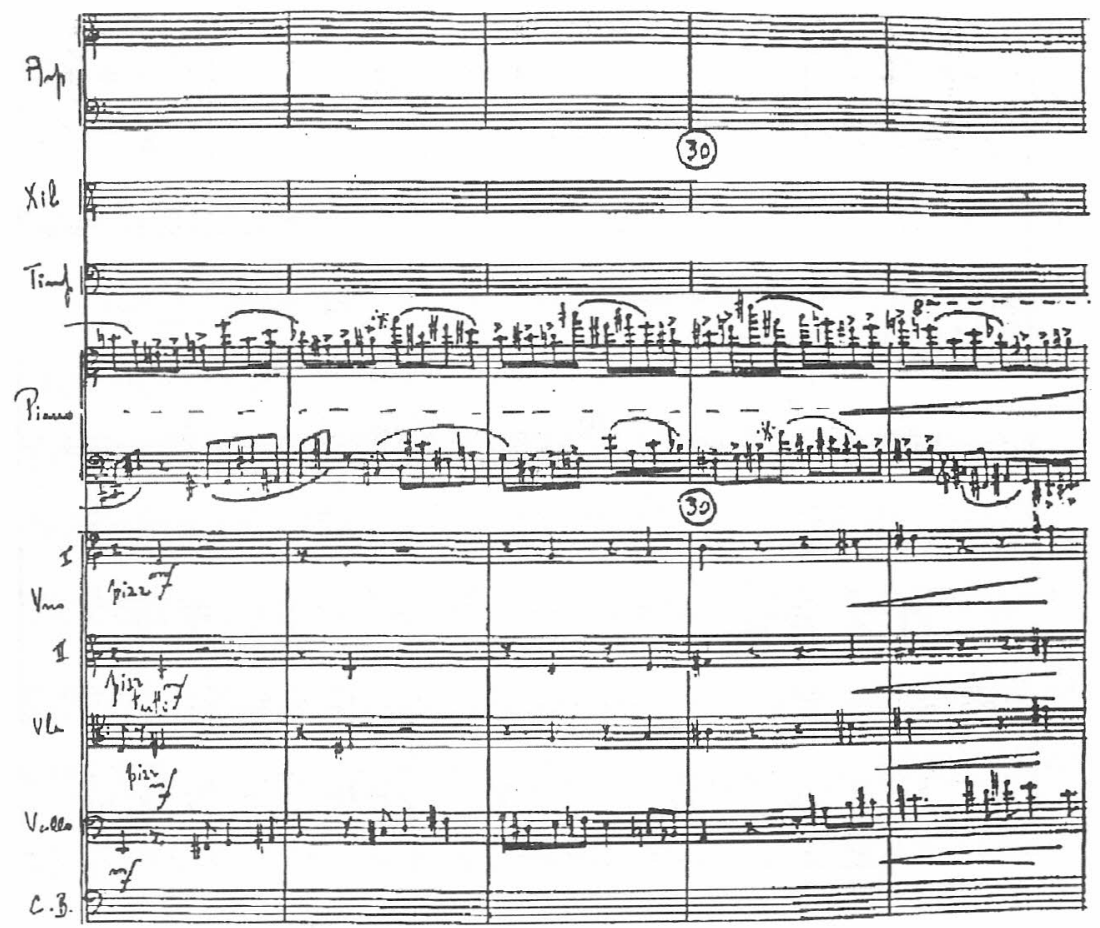

A partir do compasso 34, as cordas desenvolvem o tema alargado, continuando a enfatizar o processo imitativo.

(Ver exemplo 4 - comp. 34-38).

Encerrando a exposição, um incisivo diálogo rítmico executado, no caso, entre o piano, os tímpanos e as cordas, surge pela primeira vez para se constituir num dos elementos rítmicos de importância capital no decorrer do primeiro movimento. O piano, aqui apoiado pelos tímpanos, necessita manifestar-se com absoluta precisão rítmica, em conseqüência de seu caráter percussivo.

(Ver exemplo 5-comp. 41-44). 
Exemplo 4 - comp. $34-38$

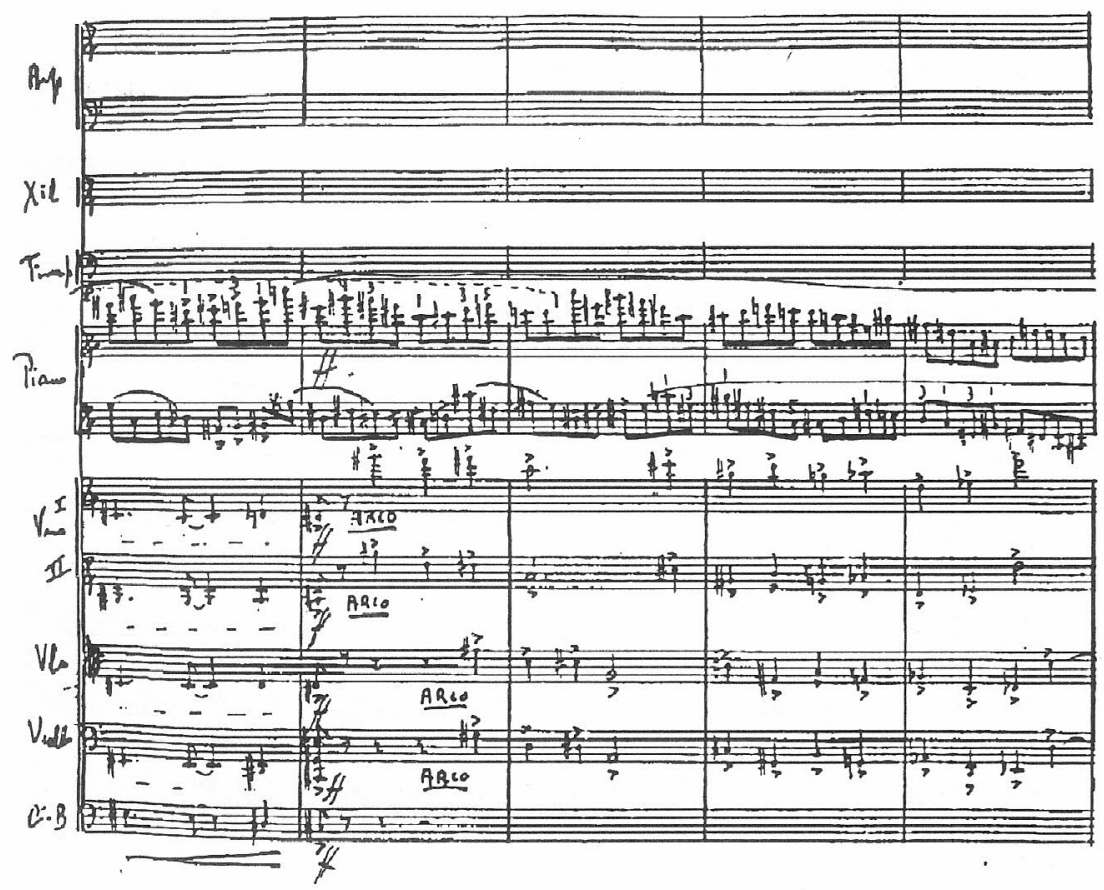

O desenvolvimento tem início no compasso 44, com solos de $1^{\text {o e }} 2^{\underline{o}}$ violinos, viola e violoncelo, podendo ser encarado como uma expansão do material utilizado na exposição. A par dos vários enfoques dados ao tema, permanecem a extrema coesão e a unidade de seus elementos constituintes.

Cada uma de suas três abordagens consecutivas é precedida por intervenções das cordas solistas e da harpa, em intervalos de $3 .^{a}$ e $4{ }^{a}$, possível alusão às famosas 3 as $^{\text {as }}$ caipiras, nomeadas por Mário de Andrade e amplamente empregadas por Guarnieri no decorrer de toda a sua obra. Evidentemente, nesse caso, o recurso é apenas uma referência diluída, sem nenhuma conotação explícita, 
como ocorre em outras ocasiões, a exemplo do Ponteio $n^{\circ} 45$ para piano solo. Essas intervenções constituem o único elemento contrastante do $1 .^{\circ}$ movimento, pois seu caráter melódico opõe-se à rítmica quase obsessiva do texto.

Exemplo 5-comp. 41-44

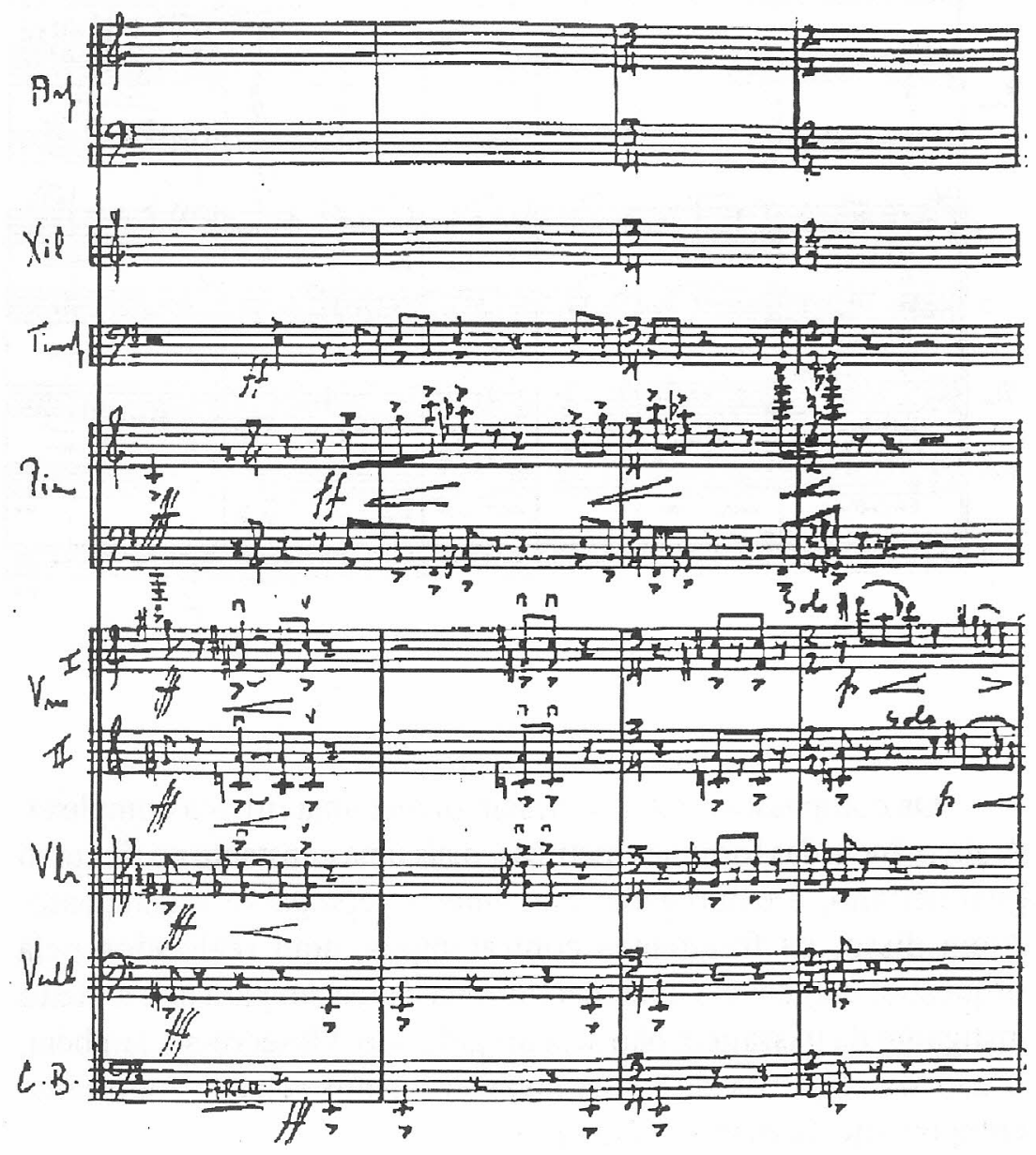


Exemplo 6- comp. 61-67

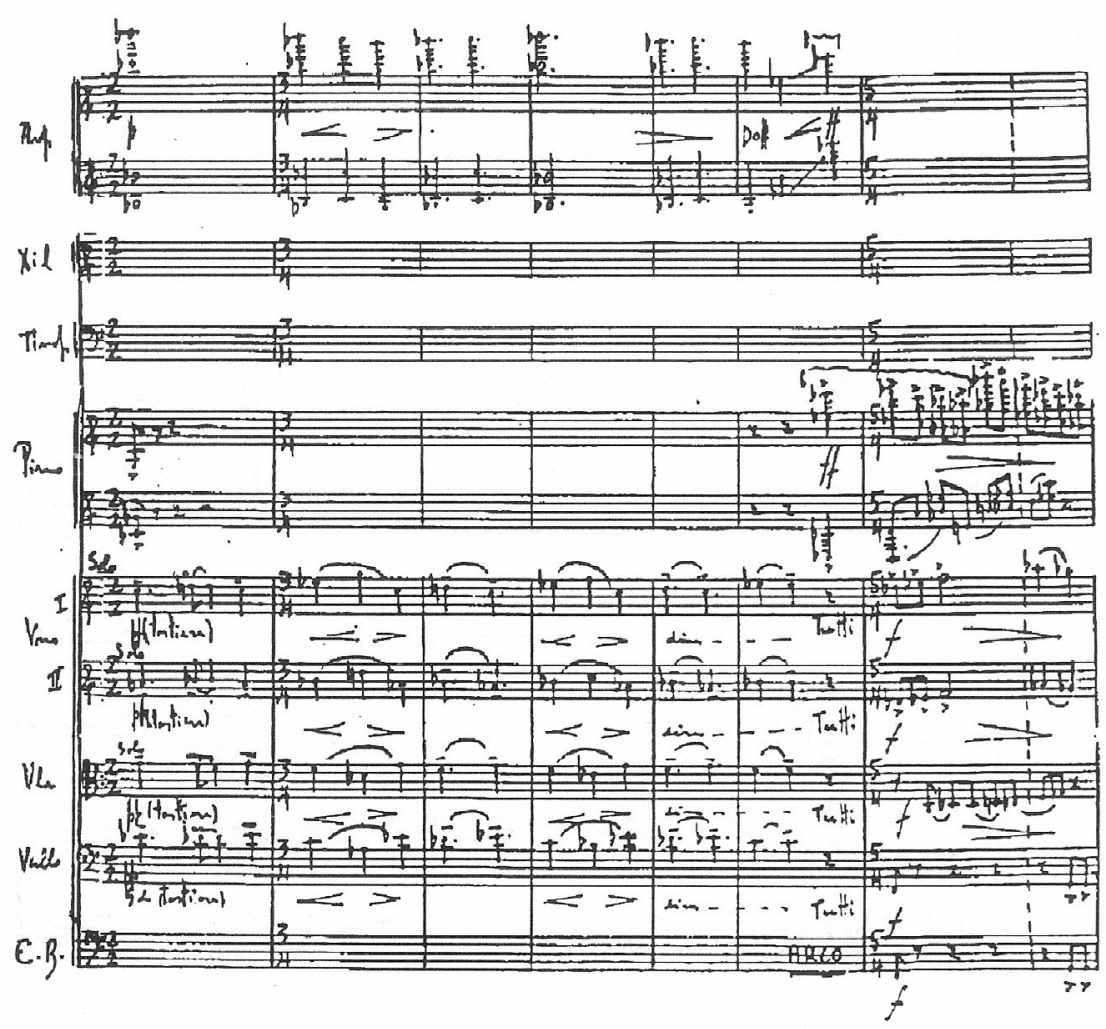

Os compassos 98 a 106 desenvolvem uma rítmica complexa. A alternância das fórmulas métricas, mais uma constante no discurso guarnieriano, é empregada, literalmente, compasso a compasso. Além disso, os freqüentes contratempos, aqui realizados pela orquestra, exigem excepcional rigor na execução para que o efeito instigante da passagem não seja prejudicado. Observe-se, também, o uso de registros distantes no instrumento solista, importante componente da pianística do autor. 
Exemplo 7 - comp. 98-103

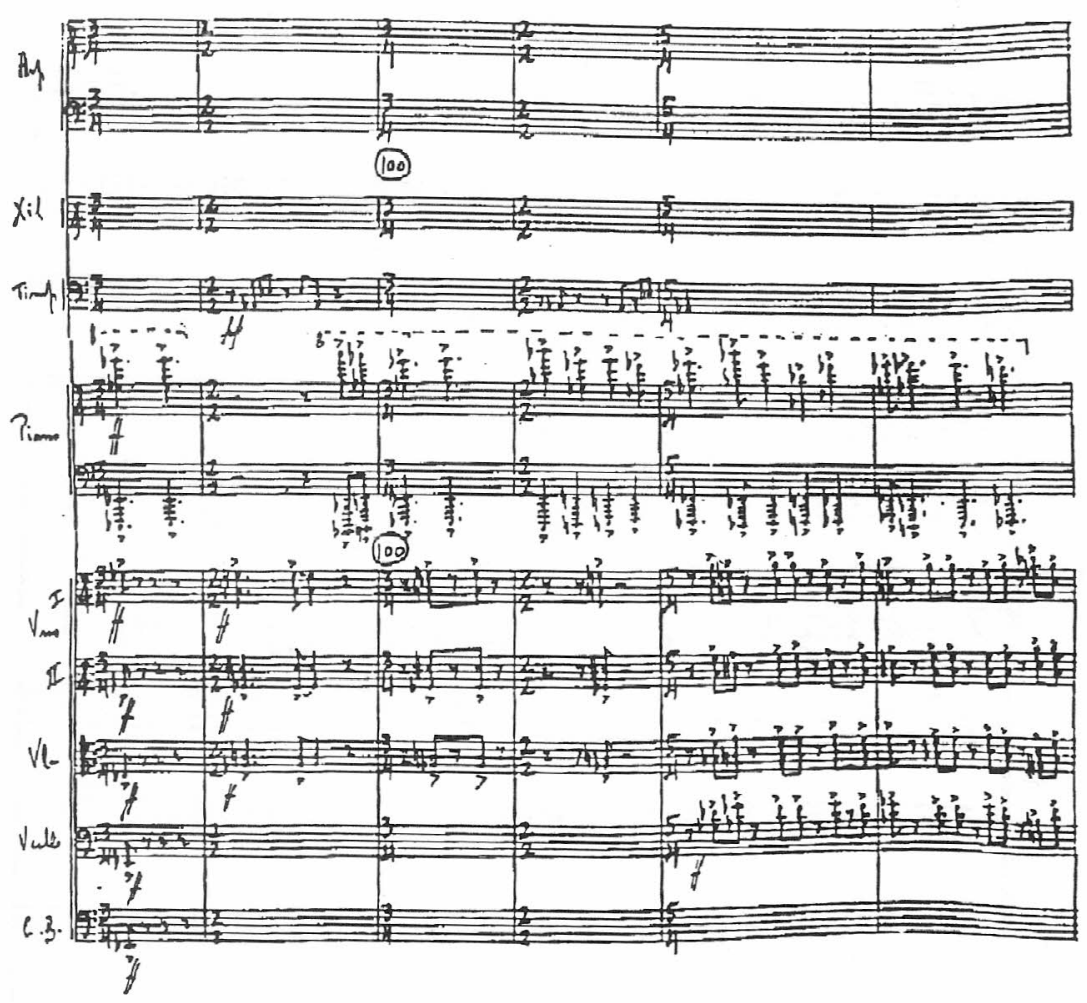

Uma pequena ponte com a indicação Piú calmo, em que o piano solista é secundado pelos solos de violoncelo e harpa, desenvolve-se com os mesmos elementos em $3^{\text {as }}$ e $4^{\text {as }}$ que precederam as diversas abordagens do tema no desenvolvimento, como podemos observar confrontando o exemplo 6 .

(Ver exemplo 8 - comp. 107-111).

Após a ponte, atinge-se a reexposição, que tem início no compasso 119, com a indicação Tempo primo. 
Exemplo 8- comp. 107-111

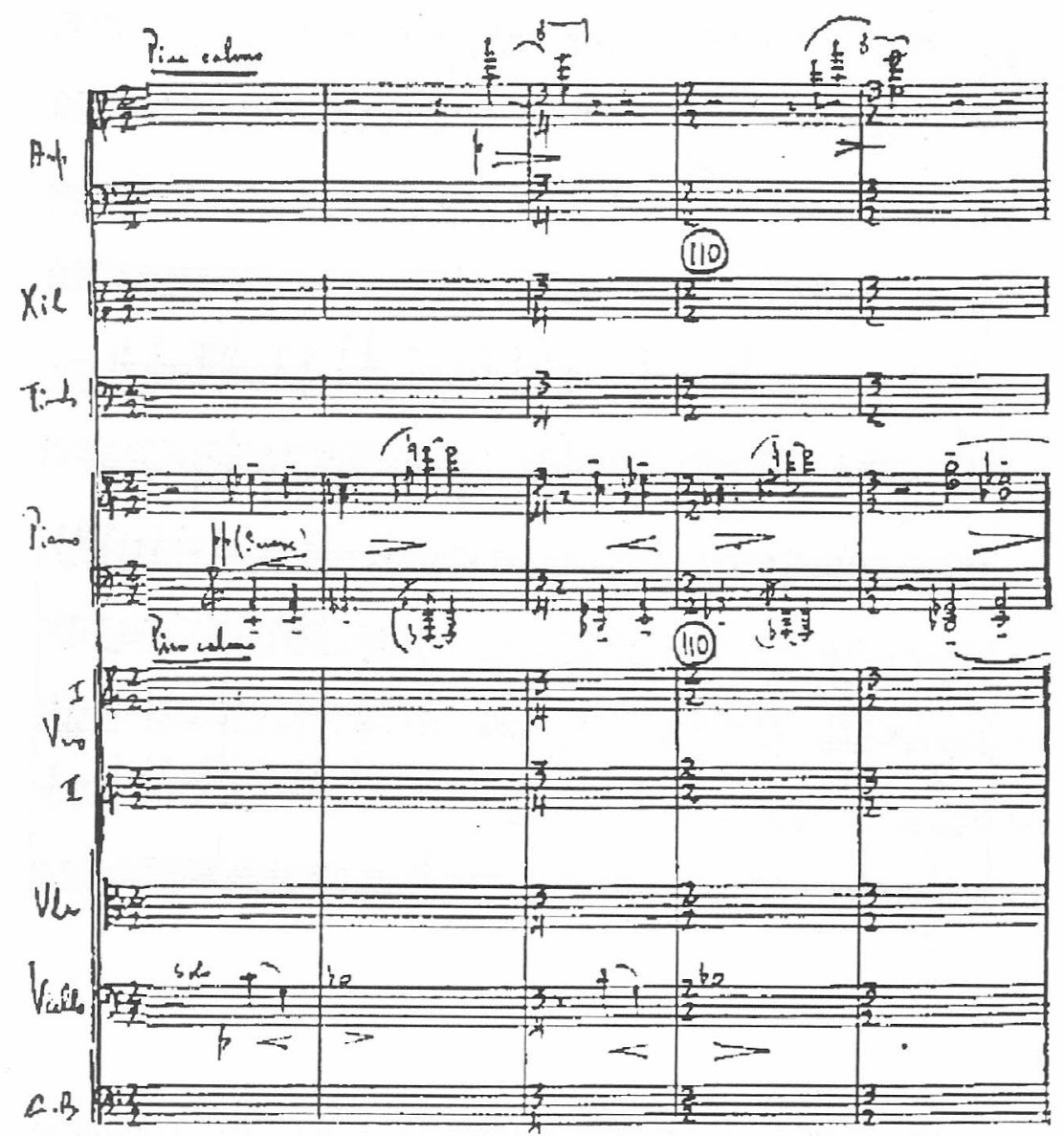

Basicamente, são utilizados os mesmos procedimentos composicionais apresentados na exposição, ou seja: ação canônica, seqüências por blocos de $7^{\text {as }}$, progressões por cromatismo, alternância constante das fórmulas de compasso, incisos rítmicos atuantes nos contratempos.

O compasso 188 introduz a coda, em que o tema principal é apresentado de forma alargada pelas cordas, iniciando-se nos 
primeiros violinos e complementando-se nas violas. Simultaneamente, o piano solista desenvolve o elemento que serviu de introdução à obra - blocos de $7^{\text {as }}$ - seguido do próprio tema em valores diminuídos, com figuração de triolets.

Exemplo 9-comp. 188-191

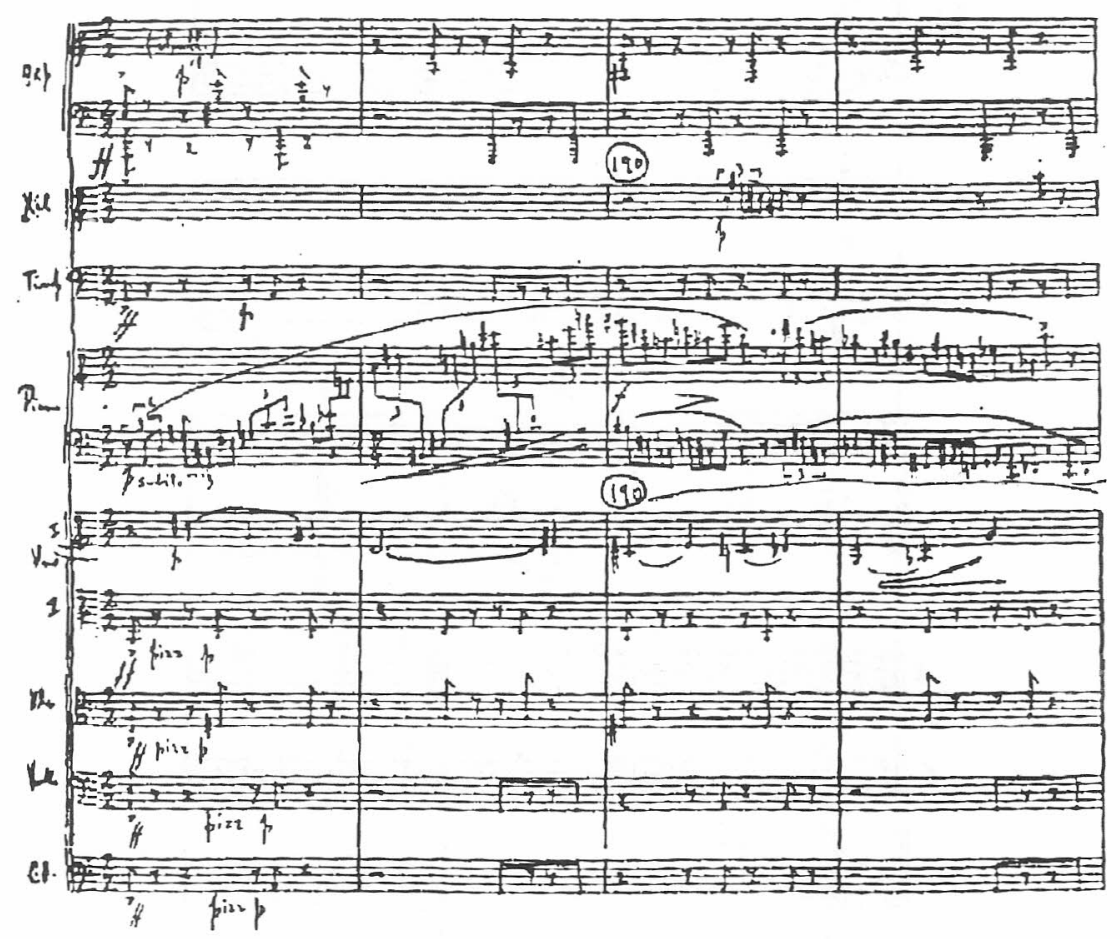

Neste ponto, é atribuída ao xilofone, que até então fizera aparições circunstanciais, uma importância contundente. Ele não só apoia o instrumento solista como também o imita nas figurações de triolets, atuando como um eco do piano.

Os compassos 205 a 212 são uma repetição dos números 98 a 106, com inversão de partes entre o piano e a orquestra. Aqui, novamente, destaca-se a absoluta precisão rítmica, confiando-se ao piano, no princípio atuando nos contratempos e, a seguir, com 
ritmo sincopado, a técnica dos saltos em acordes. Trata-se de verdadeiros chisters, cujo deslocamento sobre o teclado atinge a distância de duas oitavas.

Exemplo 10 - comp. 205-207

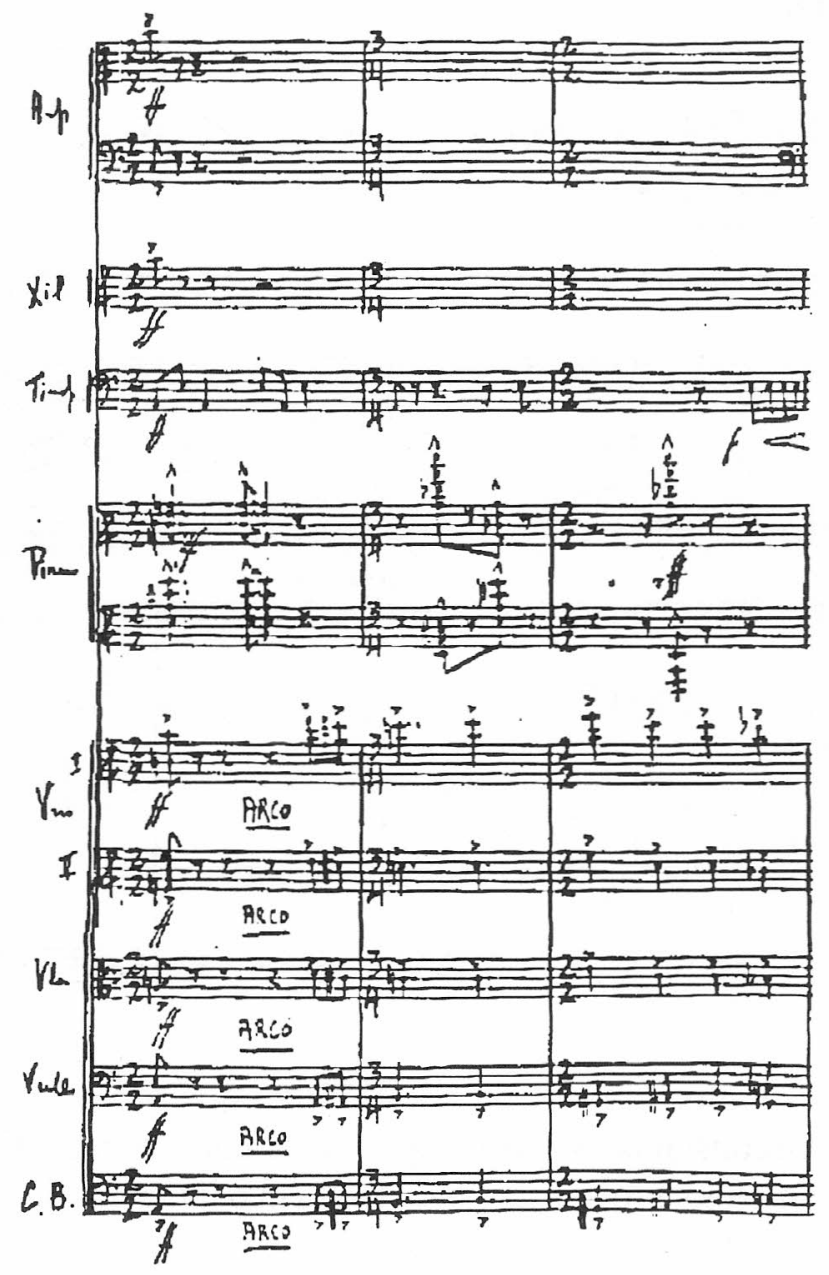

O primeiro movimento, confirmando seu centro tonal gerador (lá menor), termina com a reiteração da nota lá por todos os instrumentos da orquestra. 
Exemplo 11 - comp. 214-219

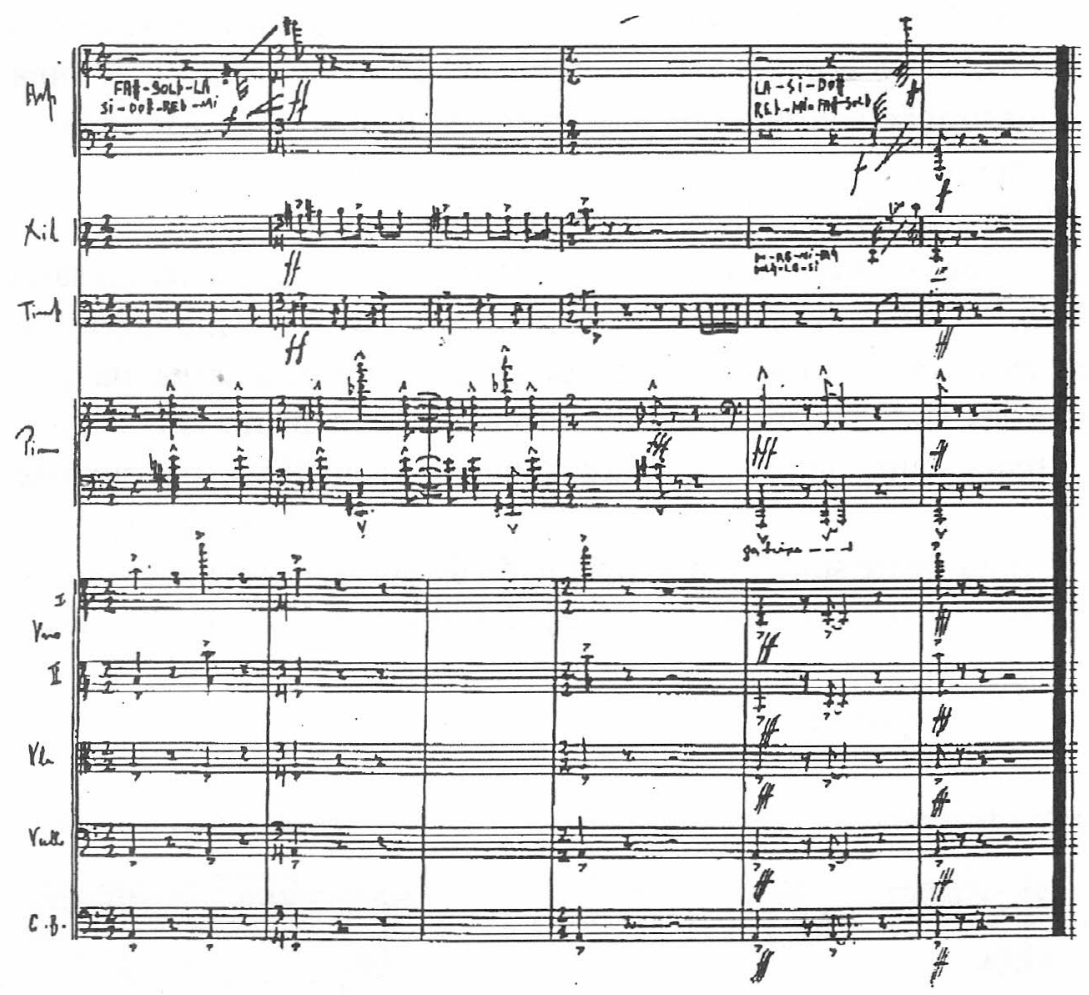

\subsection{Sorumbático}

O movimento central é essencialmente cromático, explora a riqueza dos timbres e as diversas possibilidades sonoras, que representam uma das especificidades mais marcantes da personalidade de Camargo Guarnieri.

Como tivemos a oportunidade de constatar, em várias ocasiões, Guarnieri era obcecado pelo som. A sonoridade o fascinava, servindo, não raras vezes, como elemento propulsor para a manifestação do emocional, como já observara o crítico Caldeira Filho: "É grande a sedução que a sonoridade exerce sobre a musicalidade de Camargo Guarnieri ... O valor intrínseco da sonoridade não como pesquisa tímbrica, mas como indiscreto 
revelador de segredos espirituais, é uma das características da música de Camargo Guarnieri" .

O 2. ${ }^{\circ}$ movimento da obra nos coloca em contato direto com o intimismo do compositor, que aqui se manifesta através de uma orquestração sóbria e elegante, aliada à peculiaridade dos timbres. Paisagem interior, cuja própria denominação - Sorumbático induz ao perfil psicológico do texto.

Sob a ótica da construção, trata-se de uma forma ternária A-B-A. Após uma introdução de sete compassos, em que as cordas, em pizzicato, têm seu motivo complementado pela harpa, na qual acordes superpostos sugerem bitonalidade, o piano apresenta 0 1 ํ. tema, cujas inflexões, marcadamente cromáticas, remetem-se aos contornos melódicos da nossa popular modinha. É um tema absolutamente simples, acompanhado de notas prolongadas que se deslocam cromaticamente, reforçadas pelos violoncelos e baixos.

\section{Exemplo 12}

(motivo das cordas)

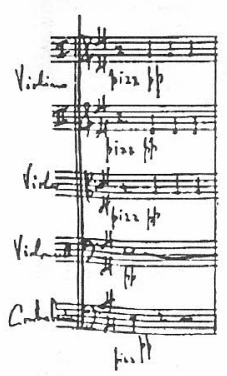

(motivo da harpa)

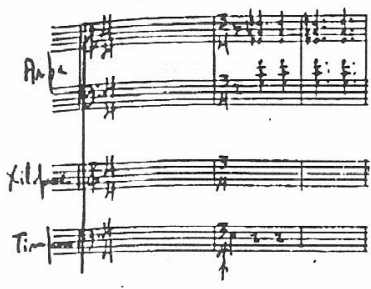

(entrada do tema no piano)

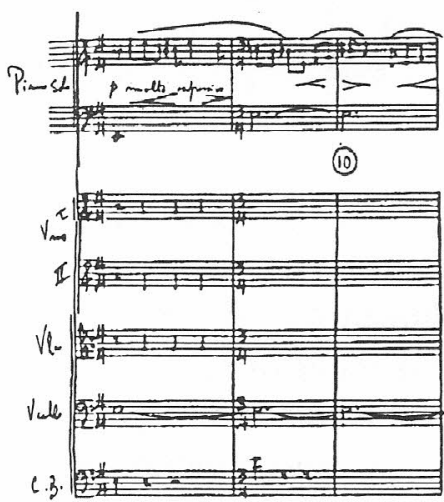

A seguir, as cordas retomam o $1^{\circ}$ tema até devolvê-lo novamente ao piano, que, após pequena cadência, deixa aos violoncelos a incumbência de introduzir o $2^{\circ}$ tema $(B)$. 
Exemplo 13 - comp. 37-41

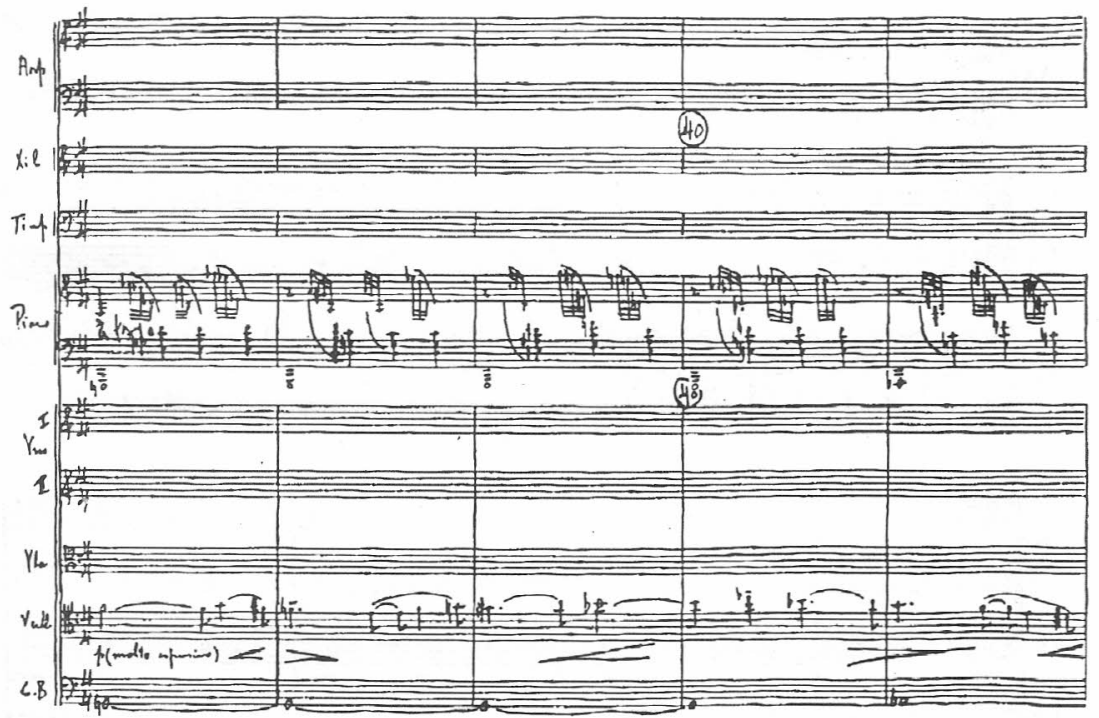

Como podemos observar, o cromatismo continua sendo o elemento preponderante na construção do novo tema. Simultaneamente à sua apresentação pelos violoncelos, o piano desenvolve um contraponto baseado na imitação rítmica dos acordes que se fizeram ouvir nas cordas e harpa, durante a introdução. Agora, notas ornamentais precedem esses acordes, em dinâmica de baixa intensidade, produzindo um timbre caracteristicamente velado.

Uma segunda aparição do tema B efetua-se no piano, a partir do compasso 45 , trazendo consigo o procedimento canônico, com a entrada das violas no compasso 47 .

(Ver exemplo 14 - comp. 45-48).

O $2^{\circ}$ tema faz-se ouvir ainda uma última vez no solo de $1^{\circ}$ violino, acompanhado de um efeito timbrístico muito original, realizado pelo piano (em tercinas), harpa e divisi dos segundos violinos, em pizzicato. 
Exemplo 14 - comp. $45-48$
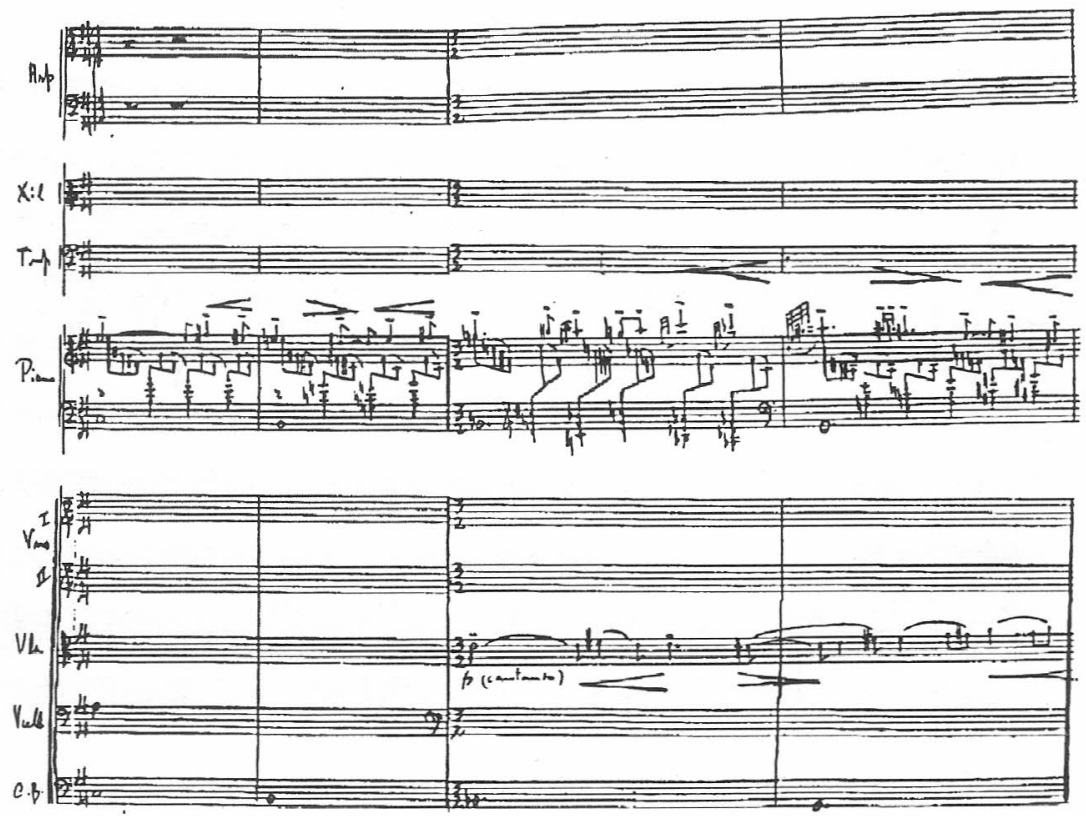

Observe-se a ocorrência de $2^{\text {as }}$ menores realizadas pelo piano, conjuntamente com as $2^{\text {as }}$ maiores da harpa e dos segundos violinos. $\mathrm{O}$ intervalo de 2 . $^{\mathrm{a}}$ é também bastante freqüentado por Guarnieri.

(Ver exemplo 15 - comp. 54-58).

Uma ponte com a indicação Poco meno desenvolve-se a partir do compasso 65. Os elementos que a constituem são retirados dos dois temas, iniciando-se por uma nova abordagem de B. Em uníssono, o piano executa a célula inicial de $\mathrm{B}$, essencialmente cromática, secundado pelos primeiros violinos.

O xilofone realiza a sua primeira incursão nesse $2^{\circ}$ movimento, respondendo à proposição do piano. Violas e harpa possibilitam a sustentação dos timbres de trinados e tremolos.

(Ver exemplo 16 - comp.65-68). 
Exemplo 15 - comp. 54-58

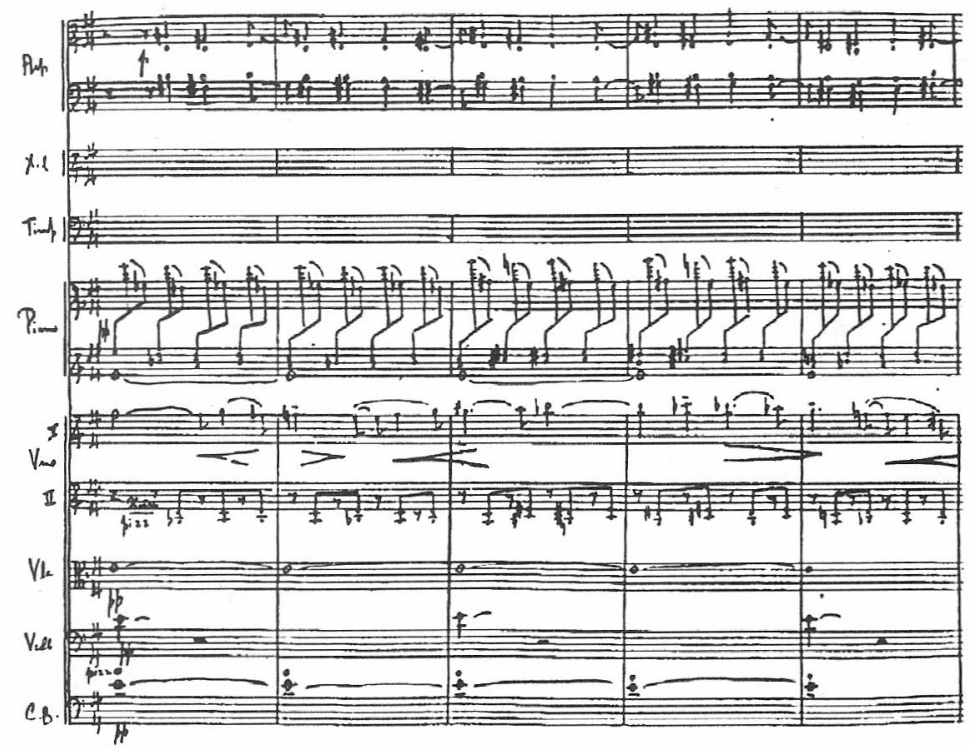

Exemplo 16 - comp. 65-68

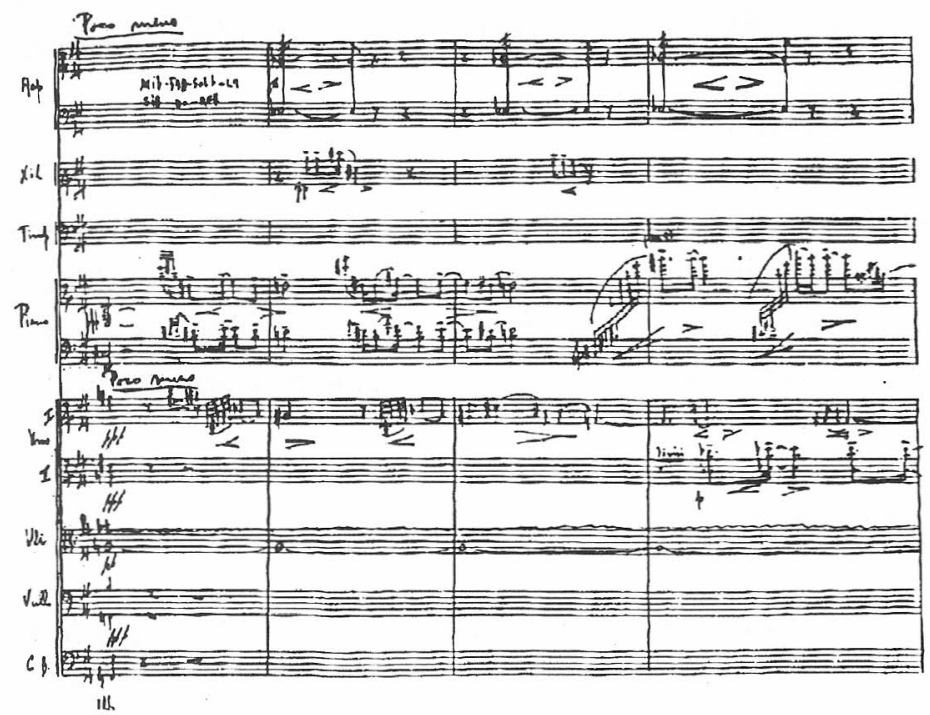


Relembrando o tema A, violoncelos e violinos atuam canonicamente em intervalos de 7. a, levando ao mesmo procedimento no instrumento solista, agora em distância de $6^{\text {as }}$.

Exemplo 17

(violinos e violoncelos)

comp.71-73

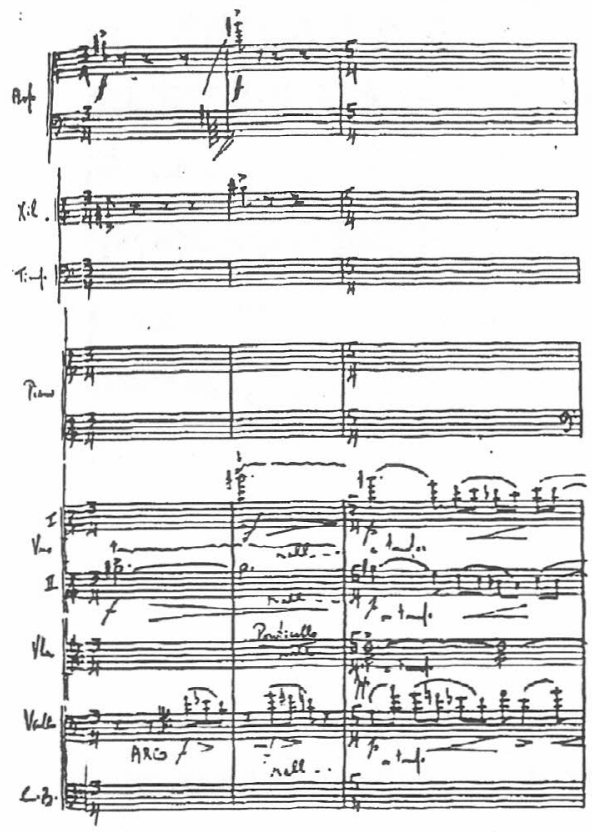

(piano)

comp. $79-80$

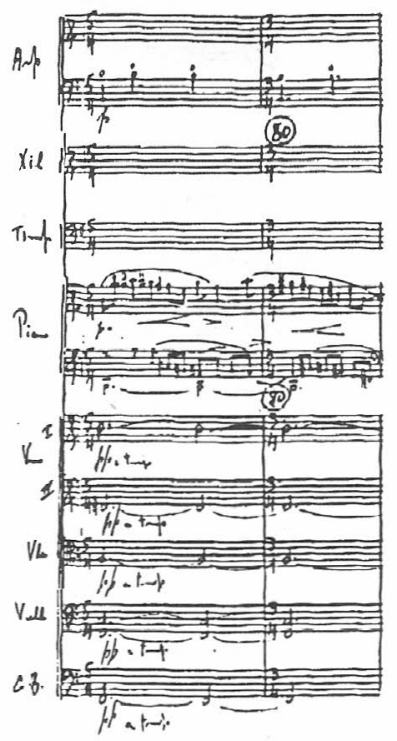

O retorno do $1 .^{\circ}$ tema ocorre no compasso 87 . Desta vez, ele é exposto, inicialmente, pelos primeiros violinos e violoncelos, cabendo ao piano, acompanhado dos segundos violinos e violas, a execução de acordes superpostos semelhantes aos da harpa na introdução.

(Ver exemplo 18 - comp. 94-98).

Os compassos de números 103 a 107 representam o ápice expressivo do movimento central. O piano complementa o tema 
iniciado pelas cordas, e estas, especificamente primeiros violinos e violoncelos, executam uma inversão da célula inicial do tema, sob o ponto de vista melódico, ou seja: o intervalo descendente de $4{ }^{\text {a }}$ diminuta (fá, mi, ré, dó\#) transforma-se em ascendente. (Ver exemplo 19 - comp. 103-104).

Exemplo 18 - comp. 94-98

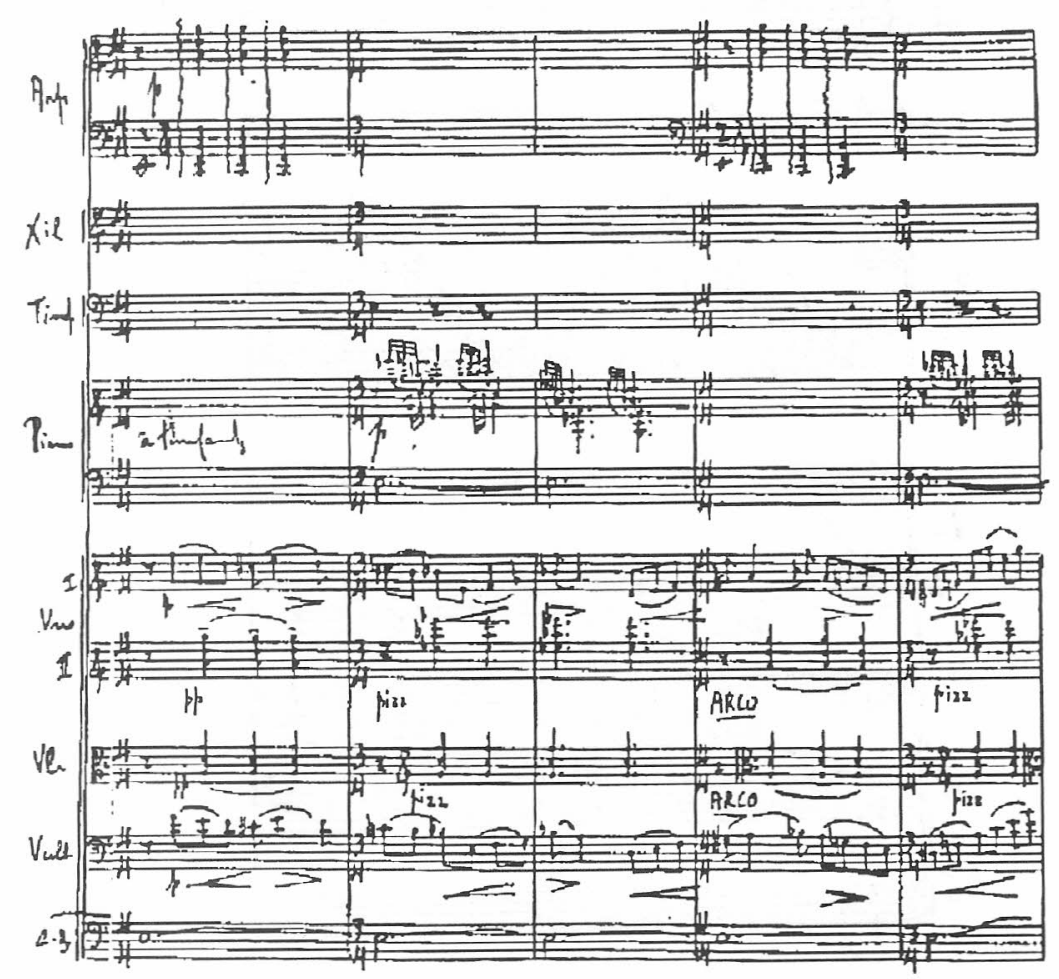

Passagem canônica, executada pela harpa, prepara a última lembrança do $1^{10}$ tema no piano. No entanto, ela não se completa. Uma ascensão em $3^{\text {as }}$, cujas indicações dimimiendo e rallentando levam à dissolução do som, é imitada pelo solo de $1^{\circ}$ violino com sordina, diferenciando-se, apenas, pela expansão do intervalo, que passa a ser de $4 .{ }^{a}$. (Ver exemplo 20 - comp. 119-122). 
Exemplo 19 - comp. 103-104

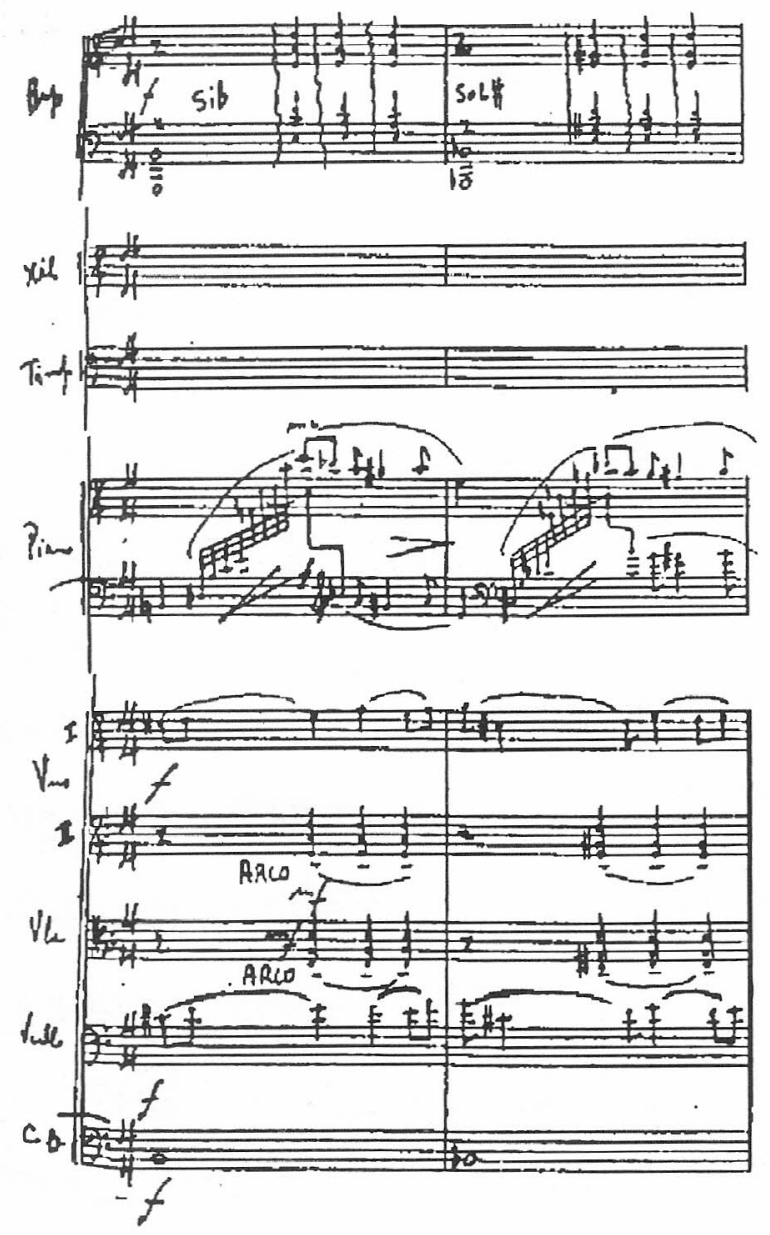

A sonoridade se extingue por completo num prolongado acorde de mi menor com $2 .{ }^{a}$ e $6 .{ }^{a}$ maiores (mi, fá\#, sol, si, dó\#, mi), encerrando o movimento.

(Ver exemplo 21 - comp. 123-124). 
Exemplo 20

Piano - comp. 119-121 1ํViolino Solo - comp. 119-122

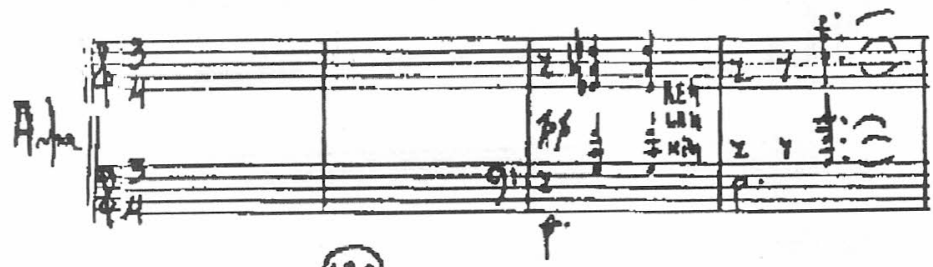

(120)
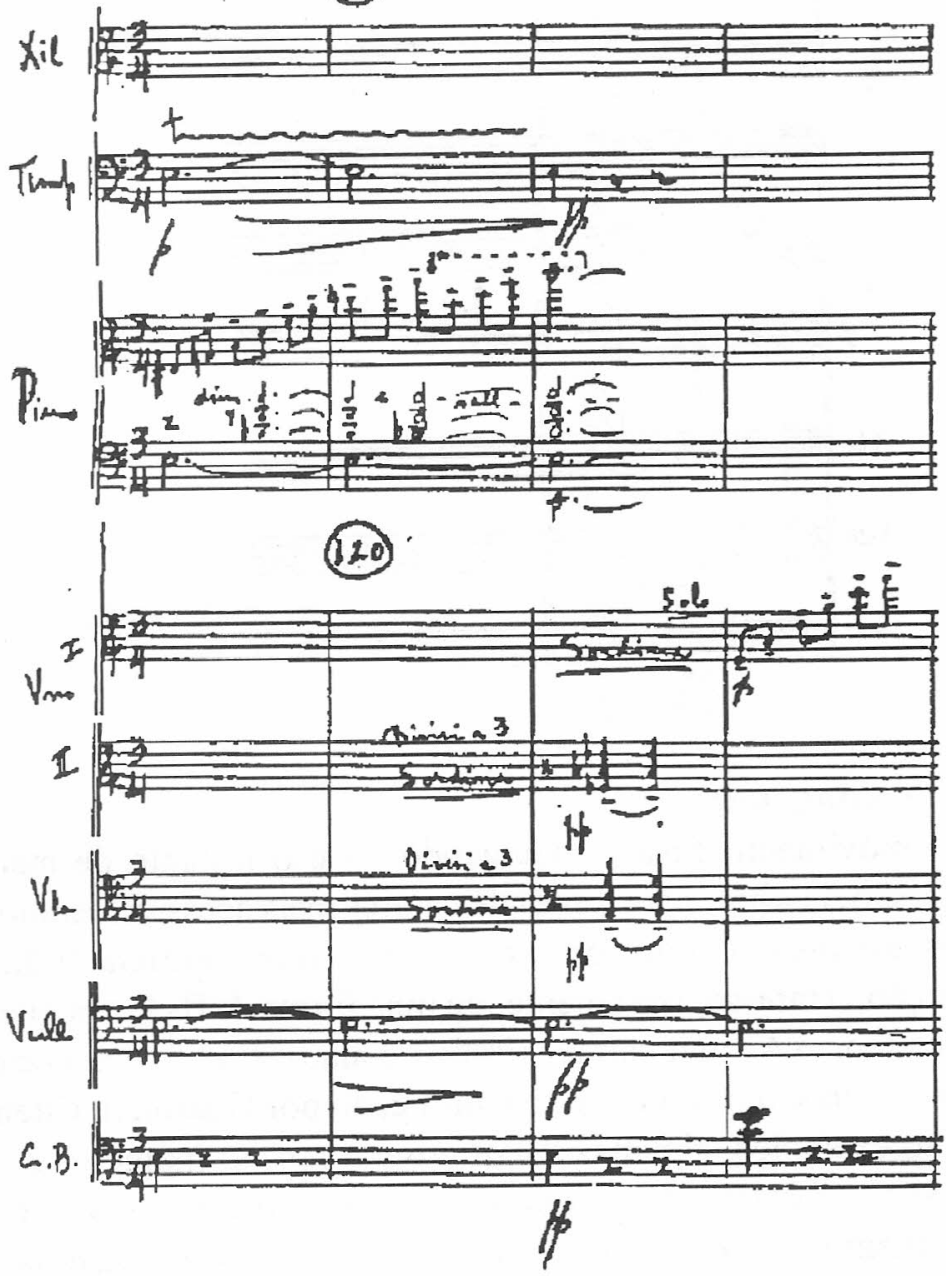


\section{Exemplo 21 - comp. 123-124}

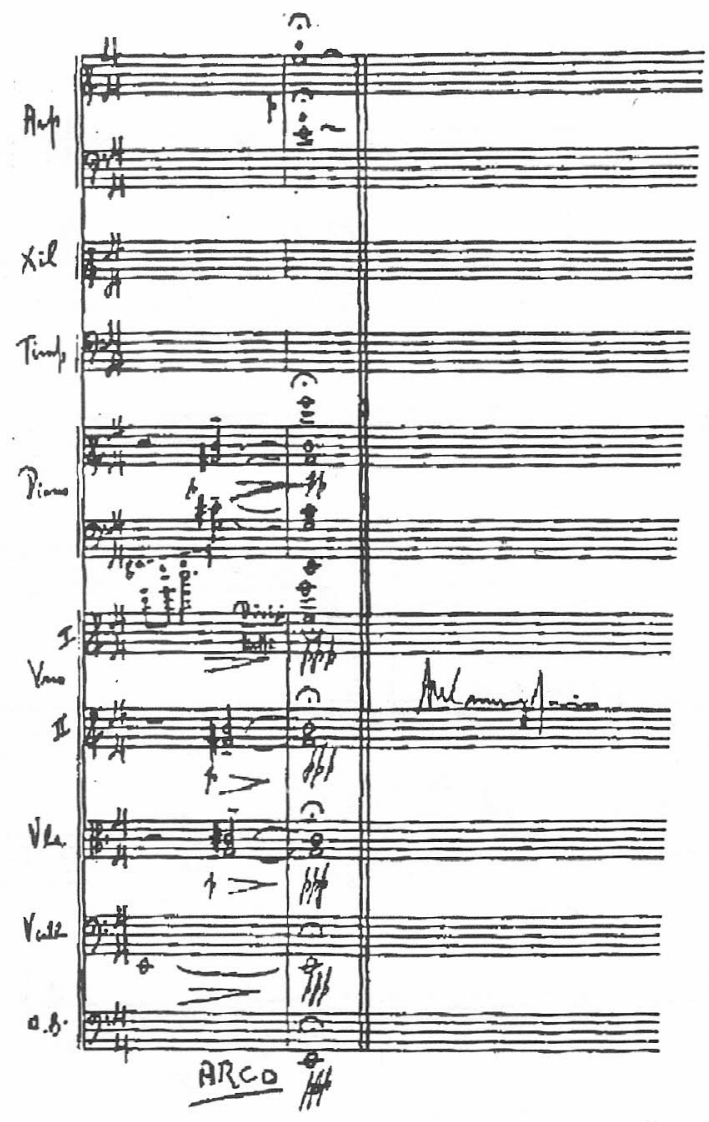

\subsection{Gingando}

O movimento final - Gingando - é o instante de maior extroversão da obra, com temas de caráter mais acessível, embora tecidos no mesmo contraponto ousado que permeia toda a construção. Trata-se, novamente, de uma forma A-B-A, em que o primeiro tema $(\mathrm{A})$ tem caráter rítmico e alude à nossa conhecida embolada, aliás, um ritmo muito empregado por Guarnieri. Citemse, como exemplos, alguimas Sonatinas para piano (números 3, 4, $7,8)$, o Concertino para piano e orquestra de câmara e o 30 movimento do Concerto $n^{\circ} 6$ (Sarati) para piano e orquestra. 
Após uma introdução de 21 compassos, em que tímpanos, xilofone, cordas e harpa estabelecem a base rítmica sobre a qual se desenvolverá o 1. ${ }^{\circ}$ tema, o piano encarrega-se de sua apresentação. Basicamente, o intervalo de $3{ }^{\text {a }}$ é privilegiado, em seqüências de mãos alternadas (1/1), conferindo caráter percussivo ao instrumento.

Exemplo 22 - comp. 22-28

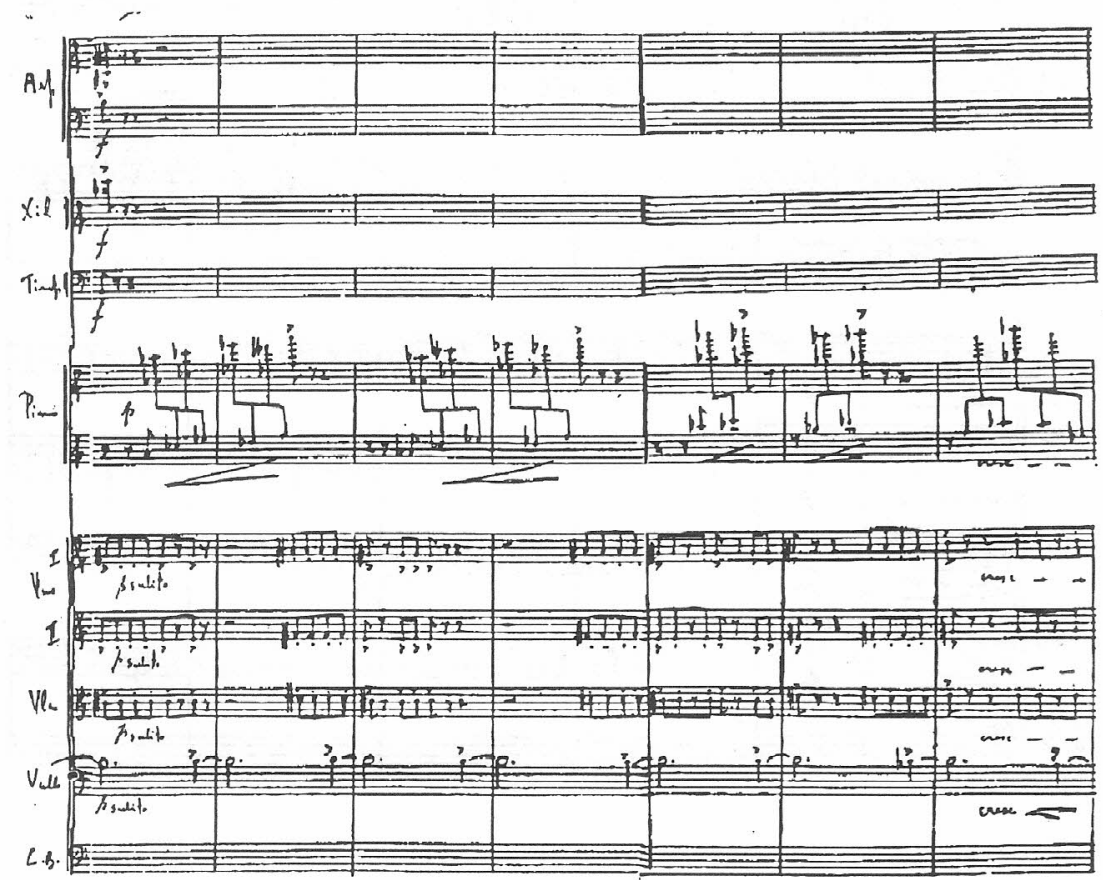

Xilofone e harpa complementam-se, possibilitando a elisão para a segunda intervenção do piano.

(Ver exemplo 23 - comp. 32-36).

Uma terceira afirmação do tema surge, ainda, no compasso 60 , precedida pelo movimento canônico das cordas, sempre em ascensão de $3^{\text {as }}$. (Ver exemplo 24 - comp. 57-62). 
Exemplo 23 - comp. 32-36

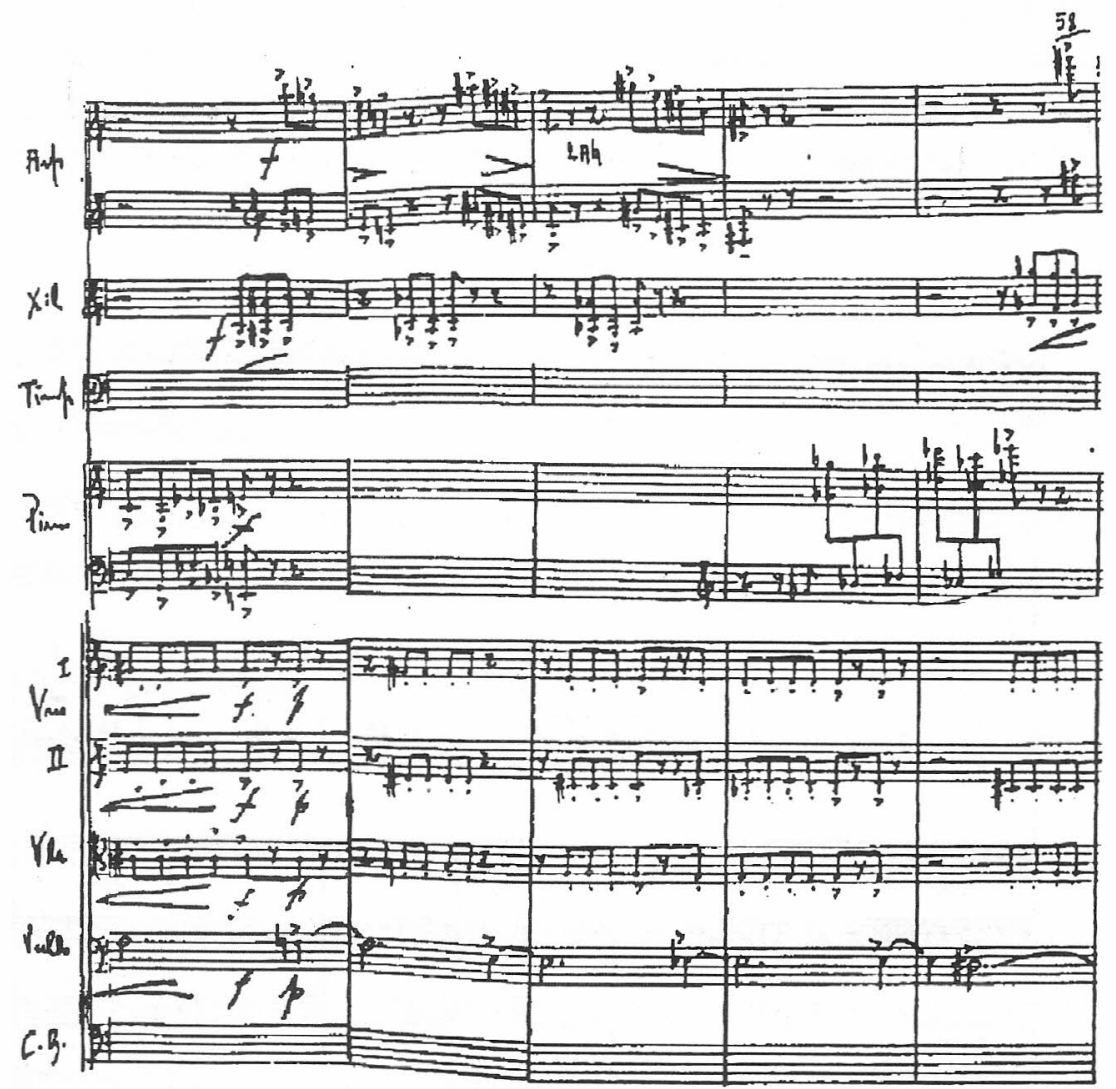

No compasso 71, tem início uma pequena preparação para a entrada do $2^{\circ}$ tema nas cordas. Guarnieriutiliza a mesma base rítmica da introdução nos primeiros e segundos violinos, enquanto violas, violoncelos e contrabaixos citam a já estabelecida seqüência de $3^{\text {as }}$ ascendentes.

O piano, por sua vez, executa um contraponto avançado, que, ritmicamente, equivale à base introdutória das cordas, em valores alargados.

A alternância das fórmulas de compasso continua uma constante. (Ver exemplo 25 - comp. 71-77). 
Exemplo 24 - comp. 57-62

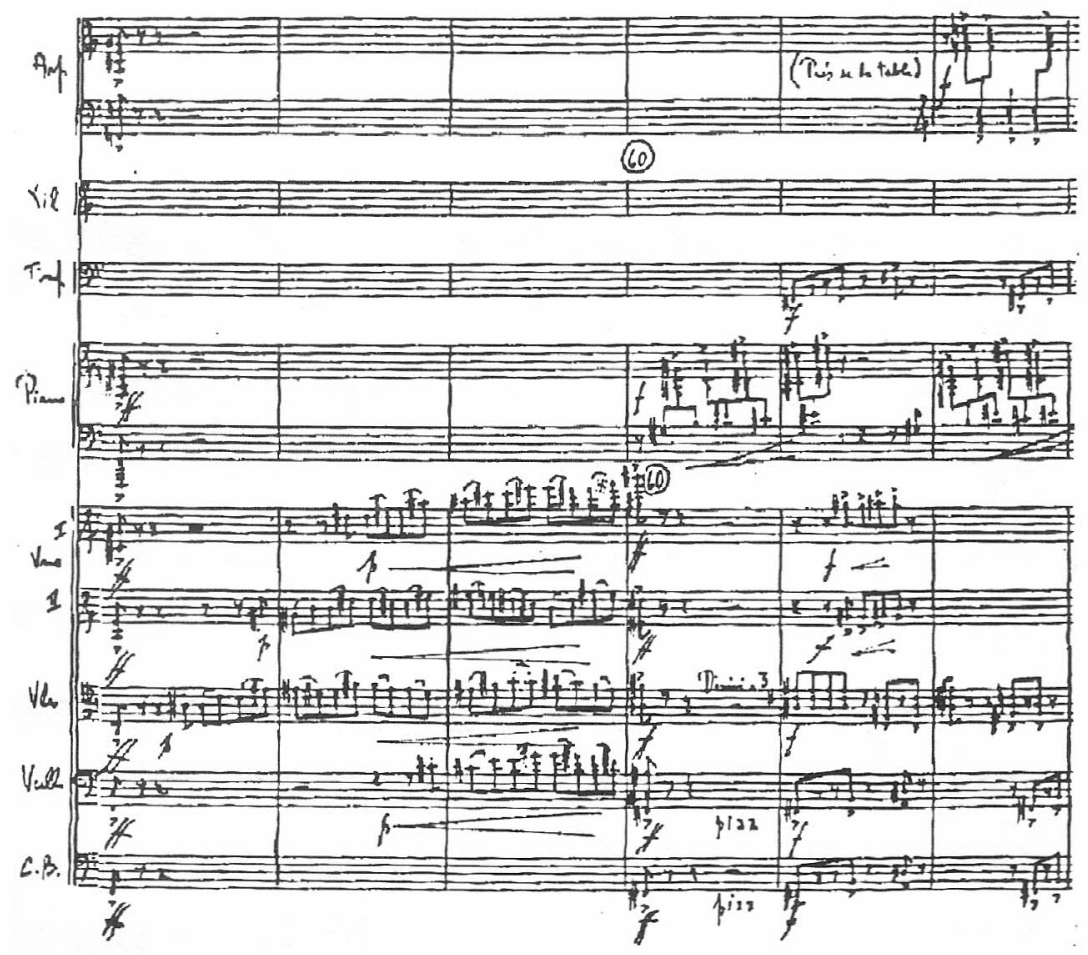

Finalmente, no compasso 80 , surge o $2^{\circ}$ tema (B) nas cordas (violinos e violas), com caráter melódico, contrastando com o tema que o precedeu.

O que devemos frisar, ainda uma vez, é a ousadia contrapontística que une o desenho do piano, totalmente independente do das cordas, à execução do 2 o tema realizada pelas cordas. (Ver exemplo 26 - comp. 80-85).

Ao término da apresentação do 2 - tema pelas cordas, o piano, a descoberto, o retoma, com ampla sonoridade e vigor. (Ver exemplo 27 - comp. 93-96).

A partir do compasso 111 inicia-se um desenvolvimento com a utilização do $1^{2}$ tema, a exemplo do que já ocorrera na ponte do 
primeiro movimento, em que o $1^{\circ}$ tema é também aproveitado antes de seu retorno propriamente dito, que se estabelece, formalmente, na reexposição.

Exemplo 25 - comp. 71-77

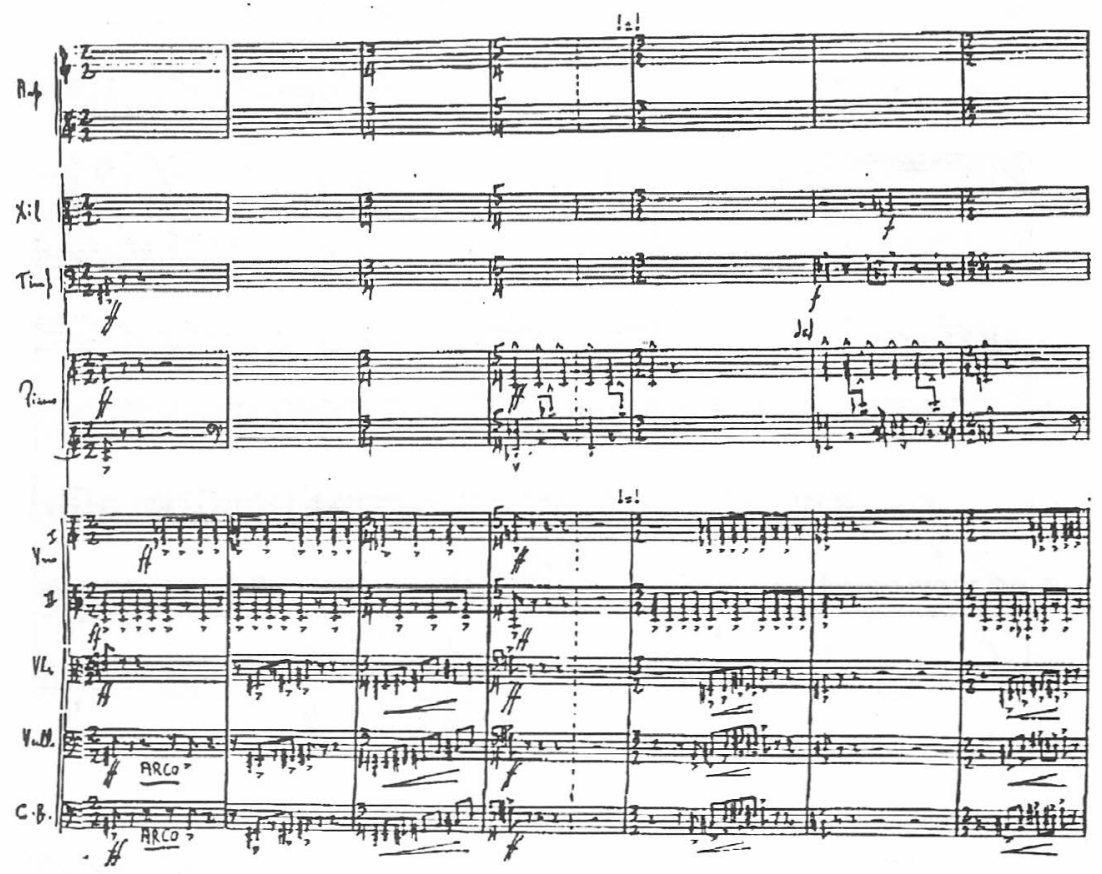

Enquanto as cordas executam a célula inicial de $\mathrm{A}, \mathrm{o}$ instrumento solista desenvolve uma seqüência de $3^{\text {as }}$ descendentes, em que podemos observar duas ocorrências interessantes: a superposição de tonalidades - politonia cromática, formada pela execução simultânea nas teclas brancas e pretas - e a distribuição das notas em agrupamentos de $3+3+2$, que, dentro de métrica binária, sugere clara sincopação. (Ver exemplo 28 - comp. 117-121).

O término da seqüência de $3^{\text {as }}$ traz uma afirmação do $1 .^{\circ}$ tema no piano, sob nova abordagem. O recurso de mãos alternadas 
(1/1) é substituído pela execução do tema em $8^{\text {as }}$ quebradas, apenas pela mão direita, enquanto a esquerda executa um desenho cromático que insiste no emprego dos $3^{\circ}$, 4ํ e $5^{\circ}$ dedos.

(Ver exemplo 29 - comp. 130-134).

Exemplo 26 - comp. 80-85

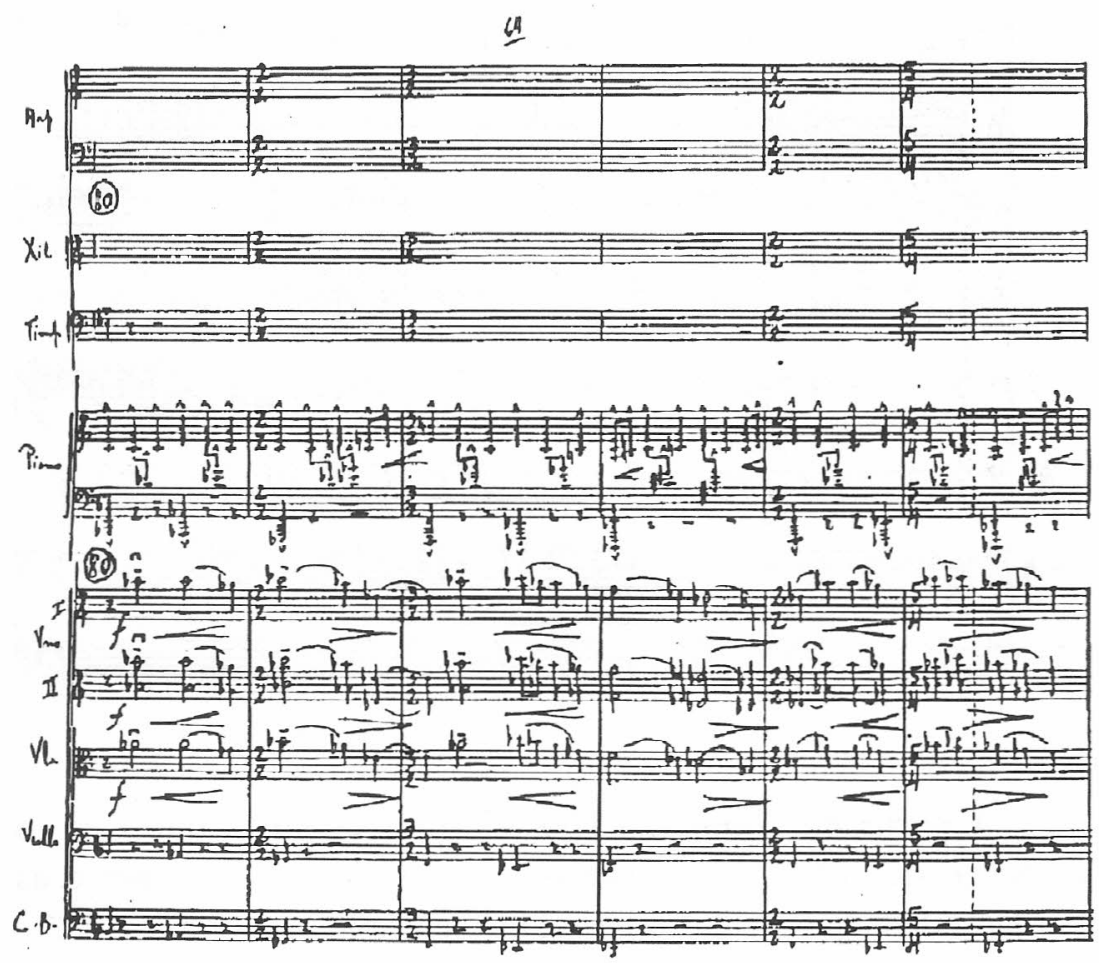

Exemplo 27 - comp. 93-96

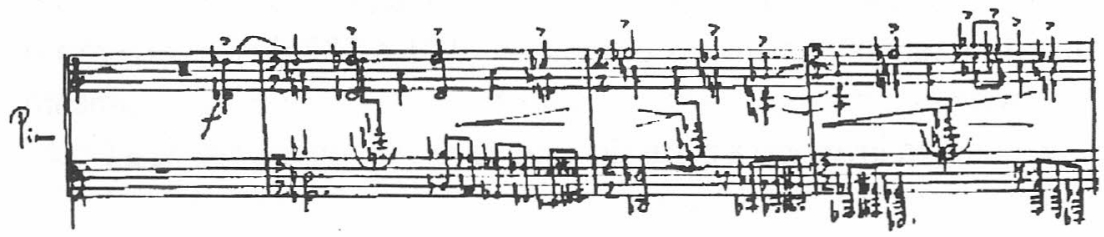


Exemplo 28 - comp. 117-121

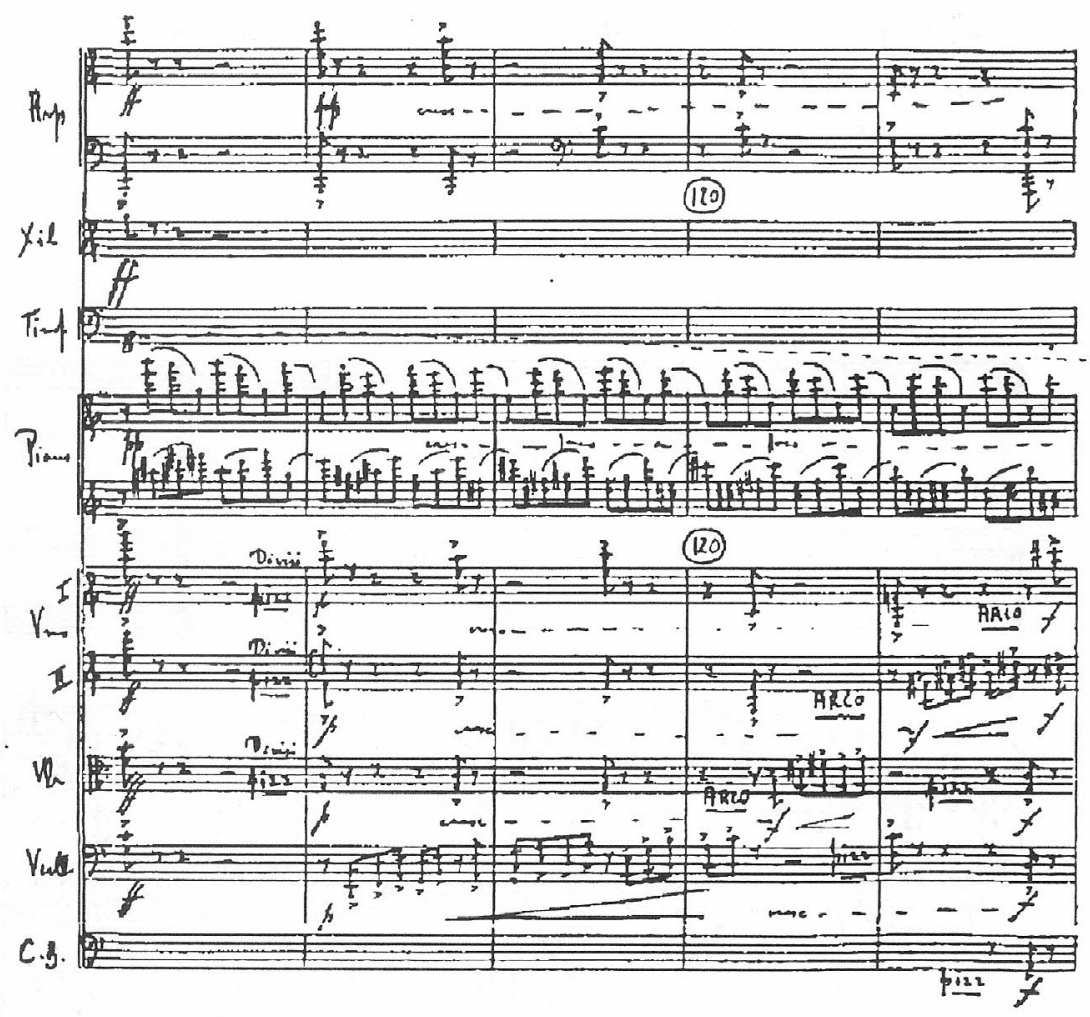

A partir do compasso 150, observa-se, ainda uma vez, o emprego de acentos deslocados (décalage) entre o piano e as cordas. Além disso, o autor insiste na técnica dos saltos em acordes sobre o teclado, atingindo a distância de duas oitavas. (Ver exemplo 30 - comp. 150-155).

O retorno da seção A ocorre no compasso 159. Basicamente, o procedimento empregado a partir daí será o da superposição dos dois temas. Assim, os compassos 171 a 182 desenvolverão o $2^{\circ}$ tema nas cordas (primeiros violinos) e o $1^{\circ}$ no piano, procedimento esse que será invertido a partir do compasso 183, onde se inicia a Coda. (Ver exemplo 31 - comp. 171-173 e comp. 183-185). 
Exemplo 29 - comp. 130-134

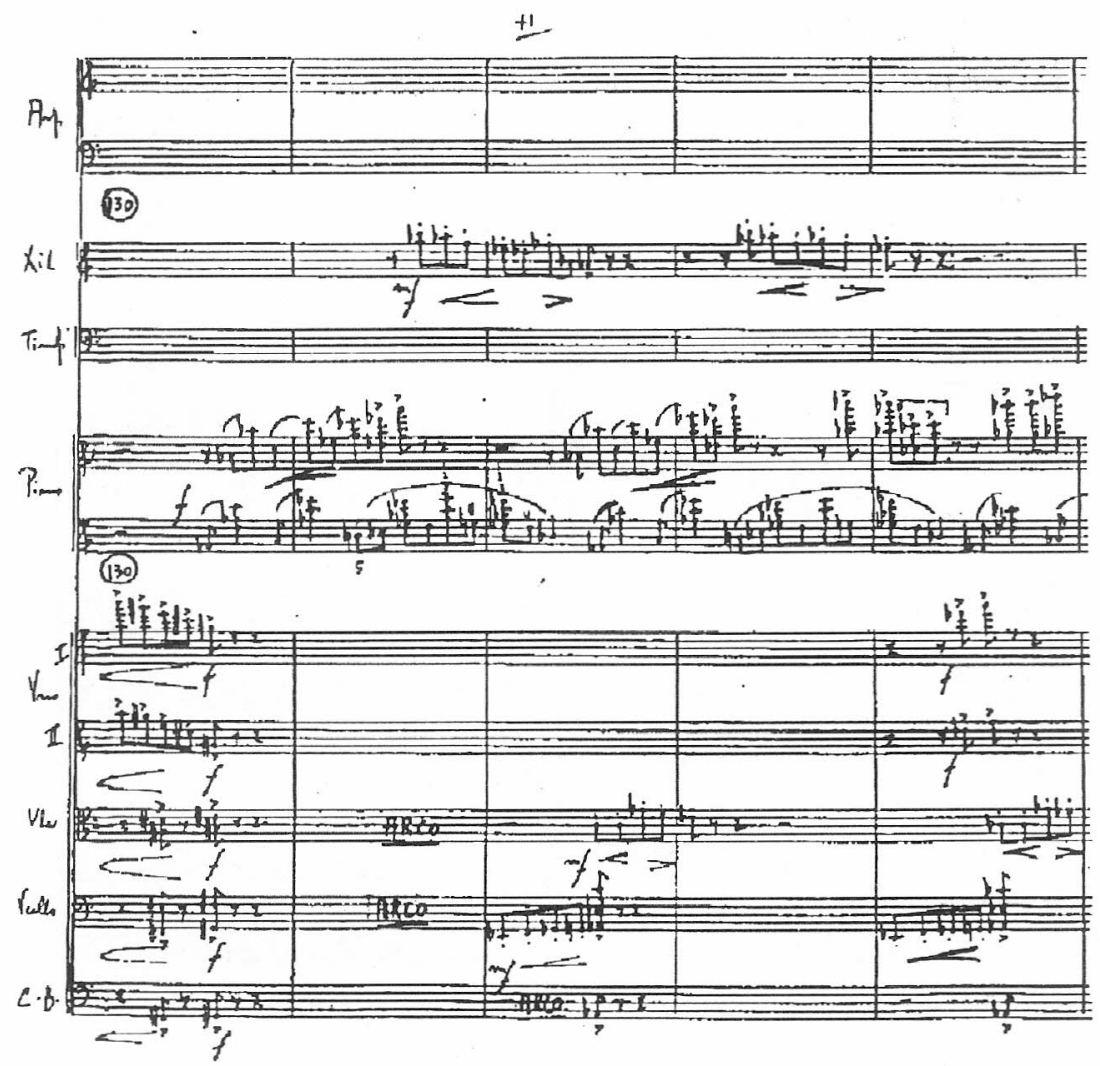

O piano encerra a obra com a execução de um desenho ascendente em $8^{\text {as }}$ alternadas, cujas figurações em triolets utilizam toda a extensão do teclado, relembrando o tema A. As cordas, por sua vez, apoiam esse desenho com uma seqüência de intervalos de 5 . $^{\text {a }}$ confirmando o centro tonal de si maior. (Ver exemplo 32 comp. 198-202). 
Exemplo 30 - comp. $150-155$

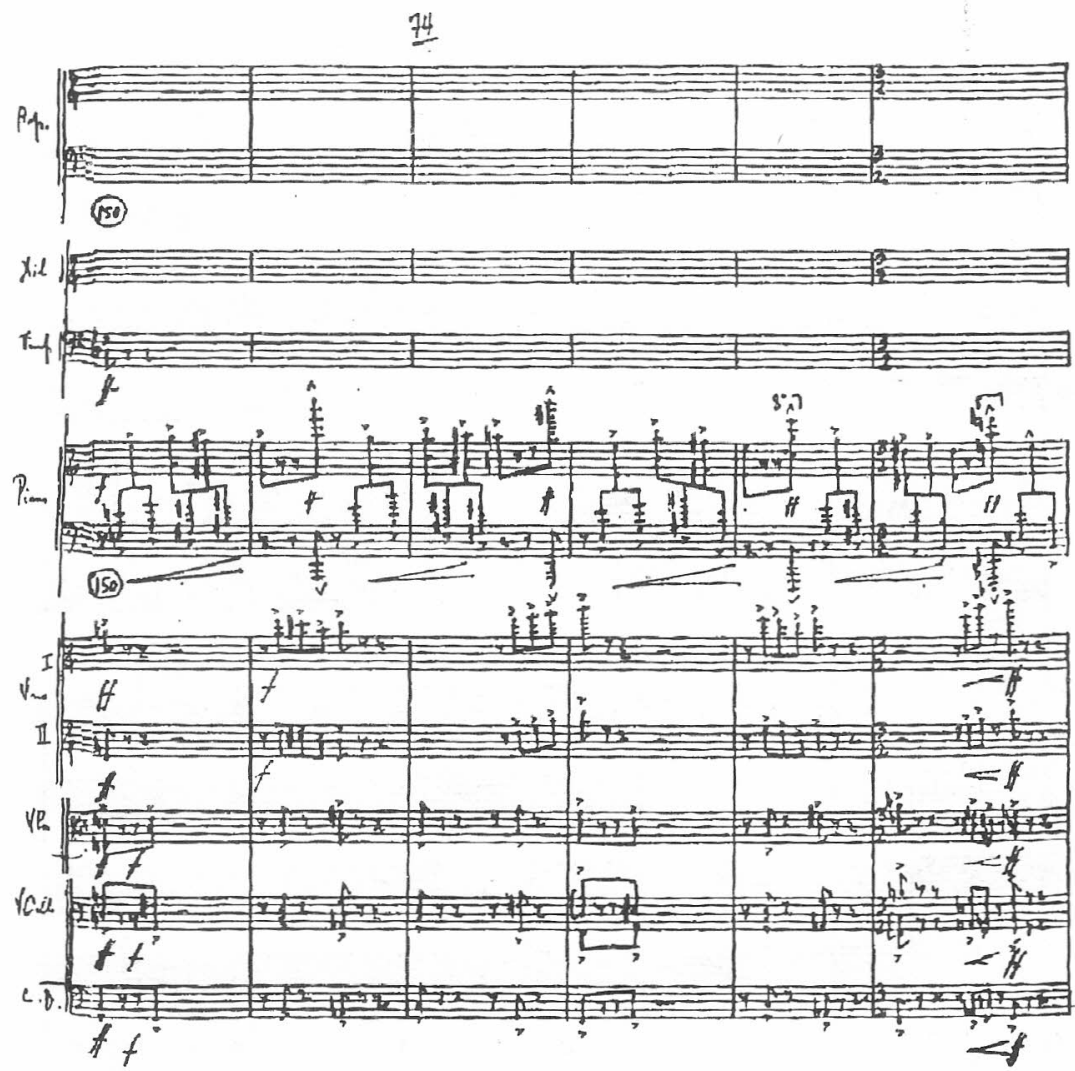

\section{Conclusão}

A análise da Seresta para piano e orquestra de câmara de Camargo Guarnieri, uma das mais significativas obras de todo o repertório pianístico nacional, leva-nos a repensar certos aspectos inerentes à personalidade do autor.

Em primeiro lugar, devemos refletir sobre a extrema coerência de suas idéias, linha mestra de sua conduta composicional. A economia de meios, a ausência do supérfluo, a clareza e a objetividade de seu pensamento estão sempre presentes, quer em 
obras de curto fôlego, quer nas grandes formas. A construção, sempre primorosa, traz à lembrança a figura do grande arquiteto sonoro, criador de painéis em que todas as peças têm vida própria, sendo impossível prescindir de uma única sequer.

Exemplo 31

comp. 171-173
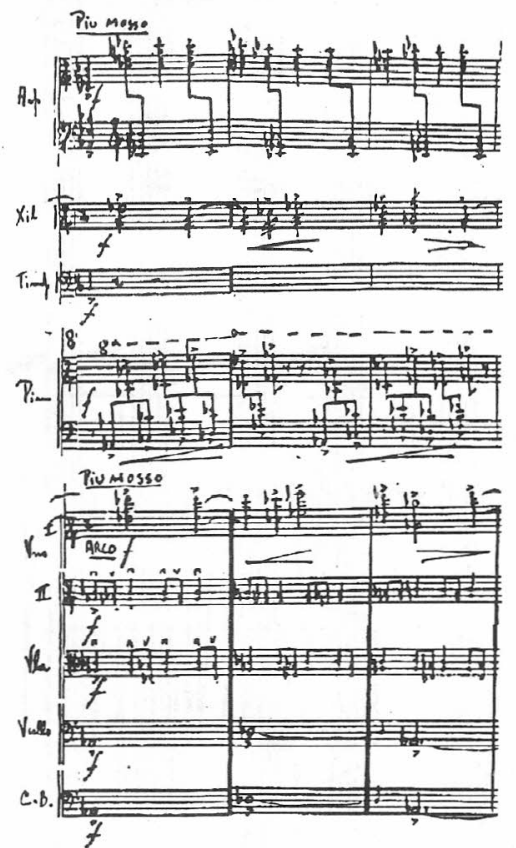

comp. $183-185$
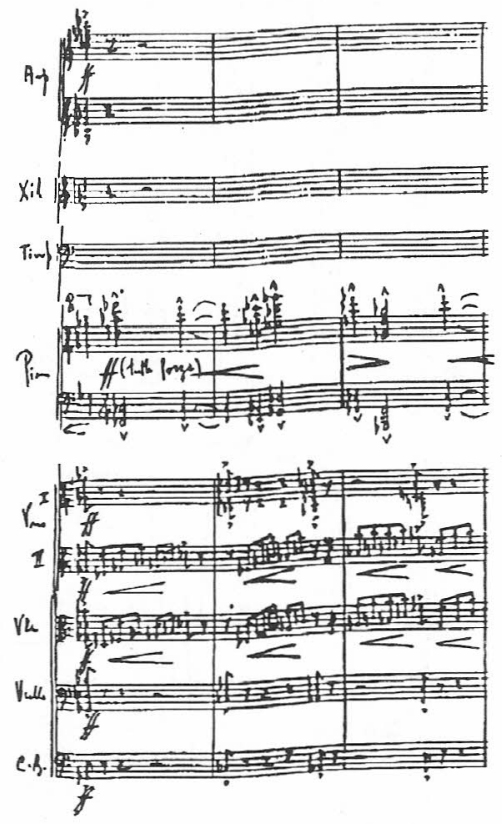

A união com o espírito nacional, muito mais que uma bandeira, como muitos soem considerar, reflete a mais íntima e verdadeira necessidade de expressão de seu inconsciente. Acima de tudo, Guarnieri amou sua pátria. Soube sentir e captar, mesmo que de maneira sutil e indireta, os ecos deste país contrastante, em que a expansão da vida e a melancolia intrínseca da raça fundem-se num todo indivisível.

Outro fator a ser considerado é a linearidade presente em sua obra, que, segundo Mário de Andrade, transformou-o no "mais hábil polifonista"7 de nossa música. 
Exemplo 32 - comp. 198-202

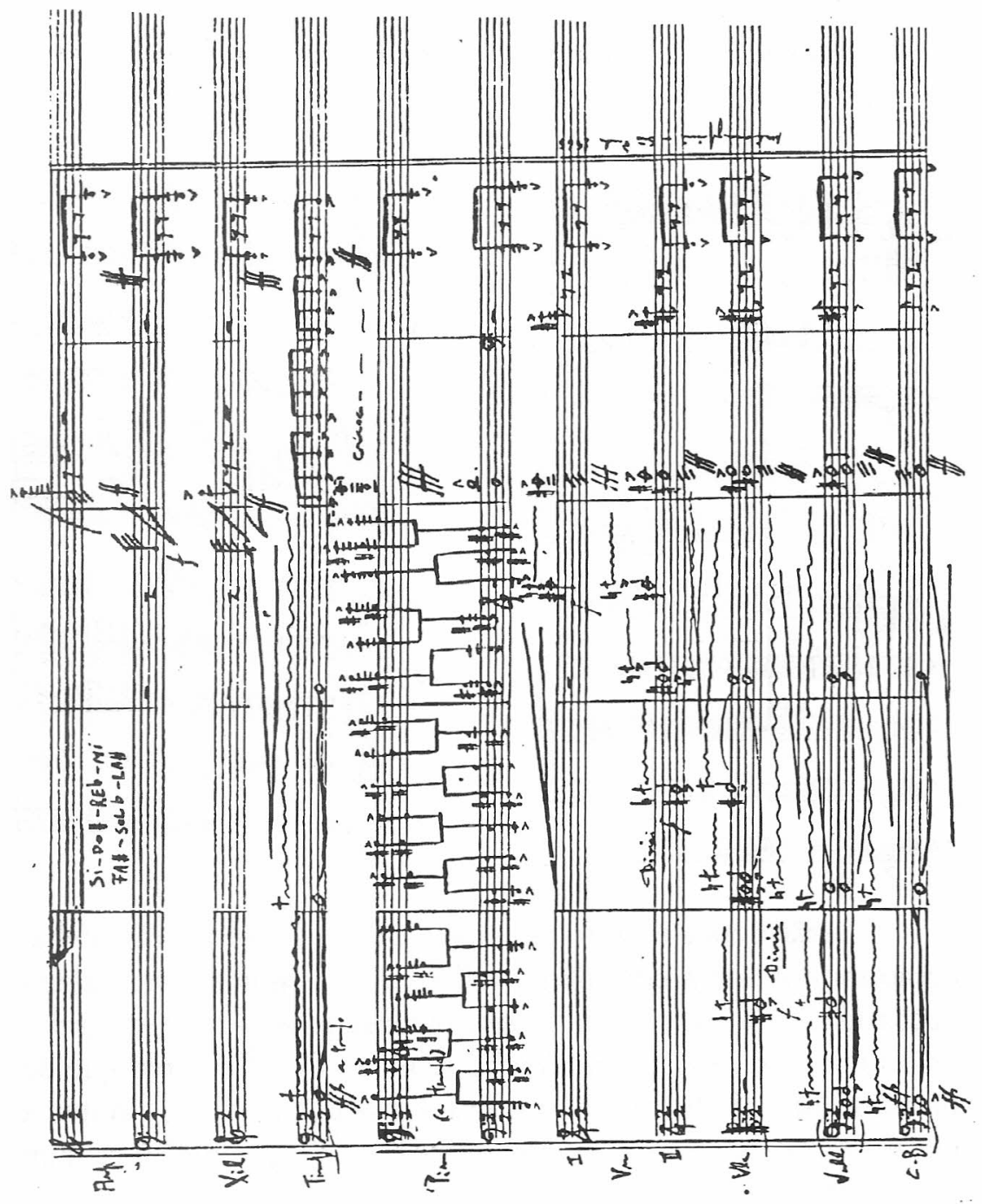


O tratamento polifônico permite-lhe a realização de uma orquestração clara, transparente, quase mozartiana, e esse ponto o distingue de outros compositores nacionais, a exemplo de VillaLobos.

Quanto ao piano, pode-se dizer que, apesar da utilização de um código conciso, a exploração dos recursos técnicos é ampla, servindo de meio efetivo para a manifestação da mensagem expressiva, destinação final da obra. Sob essa égide, Guarnieri nunca teve receio de mostrar-se, de revelar suas aspirações, de exteriorizar seus sentimentos, angústias e alegrias. O corpus de sua produção desnuda o interior de um ser humano sensivel, crente, consciente de sua missão, sabedor de que a obra de arte, para o artista, representa o verdadeiro sentido do amor e da vida. Daí a honestidade de sua música.

Sua escrita é muito pessoal, com uma dinâmica cujas cores se expandem em larga escala, indo desde ppp até fff. Além disso, o aproveitamento do teclado é integral, sendo muito comum o emprego de registros distantes.

Harmonicamente, a convivência entre tonalidade e modalidade é uma constante, observando-se também a existência de centros tonais que, certamente, dominam grande parte de toda a sua produção. A visita à atonalidade é também freqüente, comprovando a amplitude de suas propostas, como podemos constatar através de suas próprias palavras em relação à obra analisada: "O que se deve considerar é a liberdade contrapontística e a avançada concepção harmônica do compositor que, nesta obra, firma-se dentro de sua última fase, eminentemente livre de todos os preconceitos tonais".

A interpretação, aspecto em que Guarnieri se mostrava exigente e rigoroso, deve sempre buscar a mais coesa fidelidade ao texto, embora o autor fosse flexível a determinadas inflexões dinâmicas e agógicas dadas pelo intérprete, desde que não alterassem seu pensamento original. Sob esse ponto de vista, o contato autorintérprete tornava-se muito rico, pois, à medida em que o trabalho avançava, cada ponto do discurso aflorava de maneira clara e, inevitavelmente, única para a compreensão da obra. Dono de forte 
personalidade, com grande poder de persuasão, seu objetivo maior era a execução honesta, o profundo respeito pelo ato da recriação.

Diante deste repensar em relação à produção guarnieriana, resta-nos, ainda, reafirmar a necessidade de um contínuo debruçar sobre sua obra. Num país de curta memória, o descaso e o esquecimento tornam-se visões fantasmagóricas a povoar nosso patrimônio cultural, construído, muitas vezes, com a dedicação de toda uma vida, como observaria Mário de Andrade em carta a Carlos Drummond: "Os gênios nacionais não são de geração espontânea. Eles nascem porque um amontoado de sacrificios humanos thes preparou a altitude necessária de onde podem descortinar e revelar uma nação" $"$

\section{NOTAS}

1. Dedicado à autora deste texto.

2. Depoimento a Cynthia Priolli c outros, ratificado por João C. Caldeira Filho, in: Catálogo de Obras de Camargo Guarnieri, Suplemento Musical ECA/USP, vol. 1, n.o 2, dez, 1979. Prefácio.

3. M. Camargo Guarnieri, comentário sobre a Seresta para piano e orquestra de câmara. Texto publicado no programa da OSUSP de 13/03/93, por ocasião do concerto in memoriam ao compositor, realizado no Anfitcatro Camargo Guarnieri.

4. Verbete extraído do Novo Dicionário Aurélio da Lingua Portuguesa.

5. Alguns anos mais tarde, em 1972, Guarnieri faria, novamente, a opção por um só tema na construção de sua única Sonata para piano solo.

6. João C. CALDEIRA FILHO, op. cit.

7. Mário de ANDRADE, "Uma Sonata de Camargo Guarnieri", in: Revista Brasileira de Música, Rio de Janeiro, INM, mar. 1935, p. 131-135.

8. M. Camargo GUARNIERI, "Comentário sobre a Seresta para piano e orquestra de câmara". Texto publicado no programa da OSUSP de 13/03/ 93, por ocasião do concerto in memoriam ao compositor, realizado no Anfiteatro Camargo Guarnicri.

9. Mário de ANDRADE, A Lição do Amigo: cartas de Mário de Andrade a Carlos Drummond de Andrade, Rio de Janeiro, José Olympio,1982, p. 6.

\section{BIBLIOGRAFIA}

BRASIL, Laís de Souza. "O Instrumento". In: Festival Camargo Guarnieri. São Paulo, SESC-Ipiranga, maio 1994. Catálogo. 
CATÁLOGO de Obras de Camargo Guarnieri. Ministério das Relações Exteriores, Departamento de Cooperação Cultural, Científica e Tecnológica, nov. 1977. Série "Compositores Brasileiros".

MORAES, Maria José Carrasqueira de. A Pianistica de Camargo Guarnieri Apreendida através dos 20 Estudos para Piano. São Paulo, 1994. Dissertação (Mestrado) - Escola de Comunicações e Artes, Universidade de São Paulo.

PRIOLLI, Cynthia. "Reflexo de um Mestre". In: Guia do Ouvinte. São Paulo, Rádio Cultura-FM, jul. 1990.

RODRIGUES, Lutero. "Notas sobre a Seresta para piano e orquestra de chmara". In: CD Camargo Guarnieri. São Paulo, USP/Banco de Boston, Sonopress Ind. Bras., $\mathrm{n}^{\circ}$ USP-175, dez. 1996. Encarte.

Cynthia Priolli é pianista e pós-graduanda no Departamento de Música da ECA-USP. 